\title{
Design, Synthesis, Characterizations, and Processing of a Novel c-Donor-nc-Bridge-cf-Acceptor Type Block Copolymer for Optoelecronic Applications
}

\author{
Thuong H. Nguyen ${ }^{1}$, Muhammad Hasib ${ }^{1}$, Dan Wang ${ }^{1}$ and Sam-Shajing Sun ${ }^{1,2, *}$ \\ ${ }^{1}$ Center for Materials Research and Ph.D. Program in Materials Science and Engineering \\ ${ }^{2}$ Department of Chemistry, Norfolk State University, 700 Park Avenue, Norfolk, VA 23504, USA
}

\begin{abstract}
A novel c-D-nc-B-cf-A (or DBfA) type of block copolymer has been designed, synthesized, characterized, and preliminarily studied for optoectronic applications, where C-D is a conjugated donor type polyphenylenevinylene (PPV) block, nc-B is a non-conjugated bridge unit, and cf-A is a conjugated and fluorinated acceptor type PPV block. The frontier HOMO/LUMO orbital levels of $\mathbf{D}$ and $\mathbf{f} \mathbf{A}$ conjugated blocks are $-5.22 /-3.06$ and $-6.10 /-3.43$ as determined from electrochemical and optical measurements. Photoluminescence emissions of $\mathbf{D}$ and $\mathbf{f A}$ are quenched in DBfA indicating a potential photo induced charge separation pathway between the donor and the acceptor blocks. Solid state thin film studies revealed more uniform and nano-scale phase separated morphologies in DBfA as compared to D/fA blend. A two orders of magnitude enhancement of photoelectric energy conversion efficiency was observed in a best solar cell fabricated from the DBfA block copolymer as compared to a best cell fabricated from the corresponding D/fA blend. Such significant photoelectric conversion enhancement could be attributed to the improvements of phase separated and bicontinously ordered nanostructure (BONS) morphology in DBfA as compared to D/fA.
\end{abstract}

Keywords: Conjugated block copolymers, polyphenylenevinylenes, fluorinated conjugated polymers, donor-bridgeacceptor, electron transfer, photo induced charge separation, ligtht harvesting, optoelectronics, solar energy conversions, self-assembly, nano phase separation.

\section{INTRODUCTION}

Block copolymers containing electron donating and electron accepting conjugated blocks appear very promising in a variety of future polymer based optoelectronic applications such as 'plastic' solar cells, photo detectors etc. [1]. Though the overall photoelectric conversion efficiency are still relatively low, polymer based devices exhibit inherent advantages such as low cost, lightweight, flexible shape, fabrication versatility, environmental friendly, and biocompatibility as compared to their inorganic counterparts [1-8]. Understanding polymer photoelectric mechanisms and improving the conversion efficiency has become a key scientific and technological challenges on the subject. It has been established that polymer photoelectric process involve at least five critical steps: 1) photon capture or Frenkel type exciton generation; 2) exciton diffusion toward an electron donor/acceptor interface; 3) exciton dissociation or charge separation at the donor/acceptor interface; 4) charge carrier transport toward their respective electrodes; and 5) charge collection at the electrodes [1-7]. Current relative low efficiencies of polymer optoelectronic devices can be attributed to the severe losses in all those five steps, and can be

*Address correspondence to this author at the Department of Chemistry, Norfolk State University, Norfolk, VA 23504, USA; Tel: 757-823-2993; Fax: 757-823-9054; E-mail: ssun@nsu.edu categorized into losses in either energy regime or spatial regime [7, 9]. Energy regime losses are mainly due to mismatch of the radiated photon energy $v s$. the optical excitation energy gap of the polymers, as well as the mismatch of frontier HOMO/LUMO levels and work functions among the donors, the acceptors, and the electrodes. Spatial regime losses are mainly due to, for instance, the average donor and acceptor domain sizes where the exciton needs to diffuse towards the donor/acceptor interface, the continuity of the donor/acceptor phase domains toward respective electrodes for charge carrier transports, or the solid state crystallinity or packing style of the materials that affect both exciton and charge transports. Compared to the initial reported organic donor/acceptor bilayer solar cell or 'Tang cell' [2], the donor/acceptor mechanical blend cell or the so called bulk heterojunction (BHJ) cells $[3,8]$ significantly enhance the overall power conversion efficiencies (nearly one order of magnitude from about $1 \%$ to about $10 \%$ [8]). This could be attributed to the fact that the D/A interface in a blend cell is much larger as compared to the D/A bilayer cell, so that each photo generated exciton in a D/A blend would be much closer to a donor/acceptor interface as compared to a simple D/A bilayer cell with typical layer thicknesses far exceeding the average exciton diffusion length, so BHJ cells can minimize the exciton loss substantially. However, the donor and the acceptor domain sizes are not easy to control in D/A blend cells, 
and that the charge transport pathways in the D/A blend cells are typically in disordered states that could result in heavy carrier losses. Therefore, a donor/acceptor bicontinously ordered nano structure (BONS) type solid state nano morphology (such as a typical BONS type nanostructure commonly seen in a block copolymer system) appears very attractive and promising [7, 9]. A number of donor-acceptor block copolymer approaches for potential photovoltaics have been investigated and reviewed [9-17]. For instance, a conjugated donor block was covalently connected to an acceptor-bearing non-conjugated block $[10,11]$. However, charge transport in a non-conjugated polymer always presents a challenge for efficient charge transport. In other cases where a donor conjugated block was directly connected to an acceptor conjugated block without an insulating such as an aliphatic bridge unit [12, 15-17], photo induced charge separation may not be stable, as energy transfer [12] or ultrafast charge recombination could be very severe [16, 17], particularly with lack of a wide energy gap bridge unit [17]. Though a $(\mathrm{DBAB})_{\mathrm{n}}$ and a DBA type block copolymers (where a donor type conjugated block $\mathbf{D}$ is covalently linked to an acceptor type conjugated block A via a non-conjugated bridge unit B) have been developed earlier and exhibited up to one order of magnitude better optoelectronic properties compared to the corresponding blends of individual blocks in thin films [13, 14], the novel DBfA system reported here exhibited a significant or two orders of magnitude better photoelectric conversion efficiency over the corresponding D/fA system, which is an order of magnitude better in comparison to the previous non-fluorinated DBA vs. D/A system. This may be attributed to the fluorinated side chains of the acceptor block $f A$ that further enhancing the nano domain phase separation between the $\mathbf{D}$ and $\mathbf{f A}$ blocks and therefore enhancing photo induced charge separation and transport. In this paper, we report details of material design, synthesis, characterizations, processing, and device fabrications of this novel class of the DBfA copolymers.

\section{EXPERIMENTAL}

\subsection{Instrumentations and Measurements}

\section{Starting Materials and General Instrumentation}

General synthetic schemes of fA block, D block, and DBfA block copolymers are shown in Schemes 13. All starting materials, reagents, and solvents were purchased from commercial sources (mostly from Sigma-Aldrich) and used without further purification unless noted otherwise. NMR spectra were obtained from a Bruker Advance $300 \mathrm{MHz}$ spectrometer with TMS as the internal reference. Elemental analyses data were obtained from Atlantic Microlab Inc. UV-Vis spectra were collected on a Perkin Elmer Lambda 1050 Spectrophotometer. Differential scanning calorimetric (DSC) and thermal gravimetric analysis (TGA) data were collected on Perkin Elmer DSC-6 and TGA-6 systems. Photoluminescence experiments were performed on an ISA Flouromax-3 luminescence spectrofluorometer. Polymer film thicknesses were measured with a Dektak-6M profilometer. Polymer molecular weights were determined from a Viscotek GPC system via conventional calibration using a UVVIS absorption detector at ambient temperature, tetrahydrofuran (THF) as the solvent, and polystyrene standards. MALDI-TOF data were obtained from the University of Illinois MALDI facility. Thin film X-ray diffraction (XRD) studies were performed on a Rigaku D/Max-2200 TB X-ray Diffractometer (Cu Karadiation, $\lambda$ $=1.5406 \AA$ A).

\section{Cyclovoltammetry (CV)}

Electrochemical studies were performed on a Bioanalytical (BAS) Epsilon-100W tri-electrode cell system. Three electrodes include a $\mathrm{Pt}$ working electrode, an ancillary $\mathrm{Pt}$ electrode, and a reference silver electrode (either a silver wire in a $\mathrm{CH}_{3} \mathrm{CN}$ solution $\begin{array}{llllllll}\text { containing } & 0.01 & \mathrm{M} & \mathrm{AgNO}_{3} & \text { and } & 0.10 & \mathrm{M}\end{array}$ tetrabutylammonium hexafluorophosphonate or TBA$\mathrm{HFP}$, or a $\mathrm{Ag} / \mathrm{AgCl}$ wire with $\mathrm{CH}_{2} \mathrm{Cl}_{2}$ solution containing $0.10 \mathrm{M}$ TBA-HFP). For thin film measurements, polymer samples were typically dissolved in hot solvent (e.g. o-Dichlorobenzene or DCB) and then coated onto Pt working electrode. Measurement solvents used are typically those that does not dissolve polymer thin films. The CV measurements were generally performed in $0.10 \mathrm{M}$ TBA-HFP/acetonitrile solution purged with argon gas. Ferrocene $(2 \mathrm{mM}$ in $0.10 \mathrm{M}$ TBA$\mathrm{HFP} / \mathrm{CH}_{3} \mathrm{CN}$ solution) was used as $\mathrm{CV}$ internal reference standard, and its $\mathrm{HOMO}$ level $-4.80 \mathrm{eV}$ was used as the reference level. Before starting a measurement, dry argon gas was bubbled through the solution for at least 10 minutes to remove any dissolved oxygen. Between the experiments, the surface of the electrodes were cleaned or polished by acetone. Scan rate was $100 \mathrm{mV} / \mathrm{s}$.

\section{Optoelectronic Device Fabrication and Testing}

Preliminary polymer solar cell devices are fabricated and tested inside a custom built MBraum inert gas glove box system coupled with a vacuum thermal deposition chamber (vacuum up to $1 \times 10^{-7} \mathrm{mbar}$ ), a 


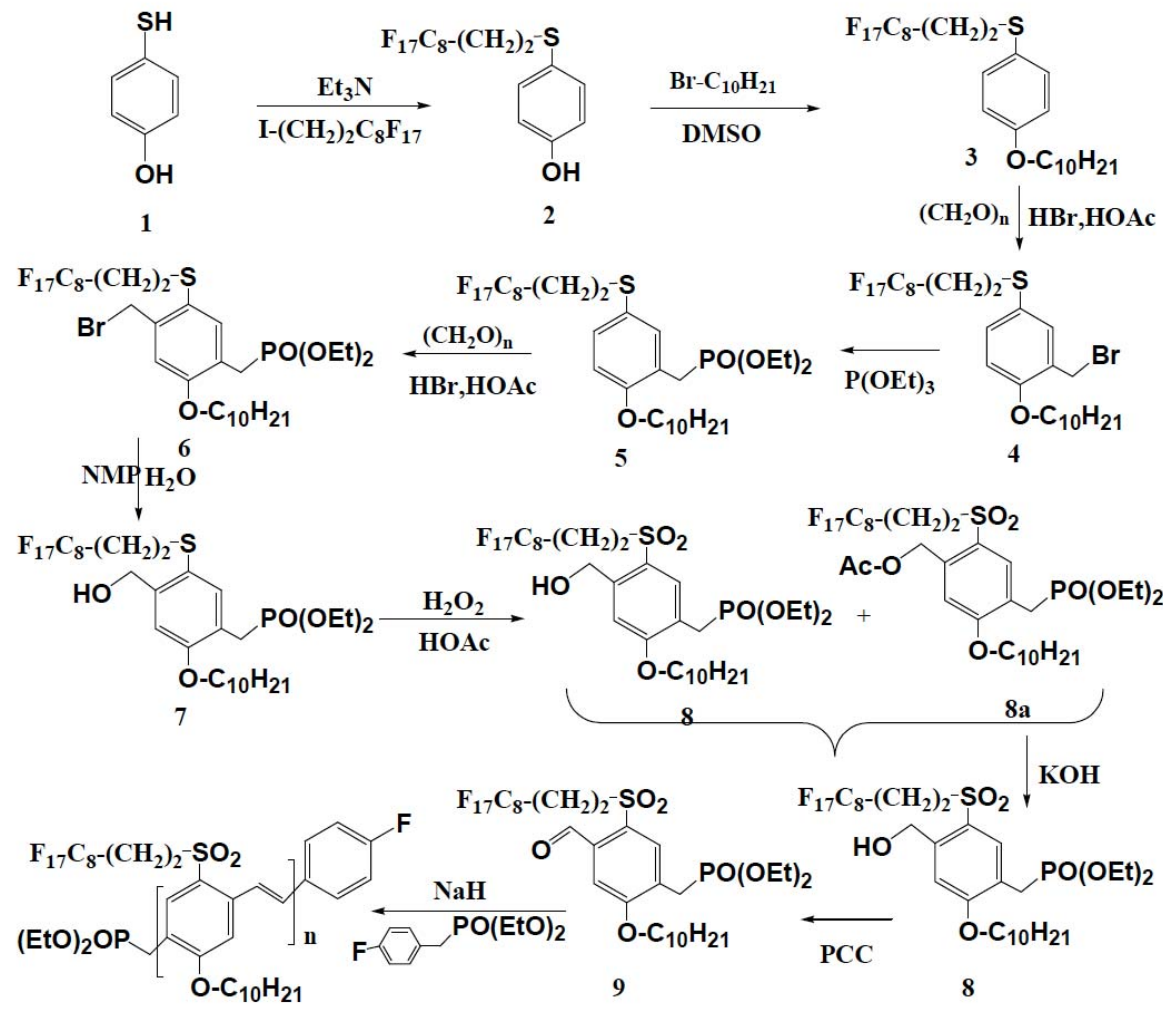

fA

Scheme 1: Synthetic scheme of an asymmetric di-functional and fluorinated monomer unit $\mathbf{9}$, and a mono-end functionalized and conjugated PPV acceptor block fA.

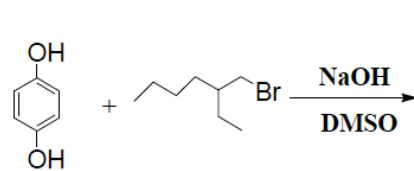

Hydroquinone

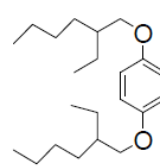

10

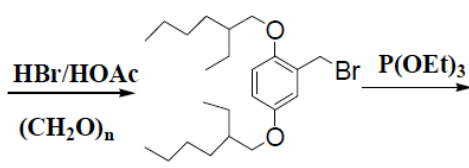

11

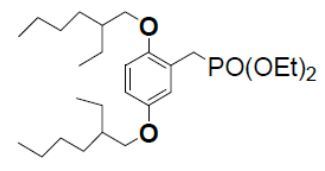

12

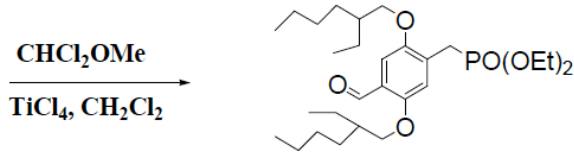

13

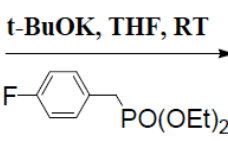

Terminator

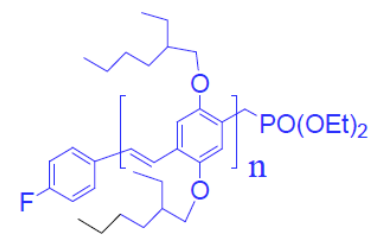

D

Scheme 2: Synthetic scheme of an asymmetric di-functional donor type monomer unit 13, and a mono-end functionalized conjugated PPV donor block $\mathbf{D}$.

solar simulator (providing a one-Sun or $100 \mathrm{~mW} / \mathrm{cm}^{2}$, 1.5 AM simulated sunlight radiation), and a currentvoltage source-measure-unit (Keithley SMU-237), and a data processing $\mathrm{PC}$.

\subsection{Materials Synthesis and Chemical Characterizations}

\section{4-(1H, 1H, 2H, 2H-perflourodecylsulfanyl)phenol (2)}

The synthetic procedure by Zhang [18] was modified as follows: To a $500-\mathrm{ml}$ two-neck round- bottom flask were added 4-mercaptophenol 1 (14.0 g, $0.111 \mathrm{~mol})$, 1-iodo-1,1,2,2-tetrahydroperfluorodecane $(75.0 \mathrm{~g}, 0.1307 \mathrm{~mol})$, triethylamine $(11.2 \mathrm{~g}, 0.111 \mathrm{~mol})$, and $55-\mathrm{ml} \mathrm{THF}$. The mixture was refluxed at $85^{\circ} \mathrm{C}$ for 9 h. The mixture was cooled to room temperature (RT), diluted by $100 \mathrm{ml}$ of water, added $5.0 \mathrm{ml}$ of $2 \mathrm{~N} \mathrm{HCl}$, extracted with $700 \mathrm{ml}$ hexane. The hexane extract was dried with $\mathrm{MgSO}_{4}$ and filtered. The crude product was purified by column chromatography with silica gel (1:6, ethylacetate: hexanes) to give $60.0 \mathrm{~g}$ of white powder product. Yield: $95 \%$. ${ }^{1} \mathrm{H}$ NMR $\left(\mathrm{CDCl}_{3}\right.$, also see Figure 


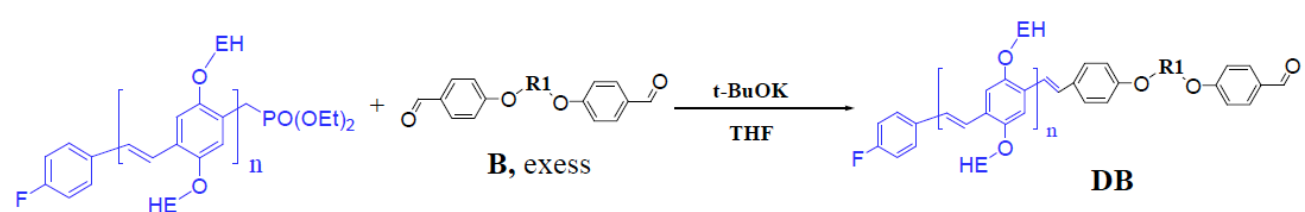

D
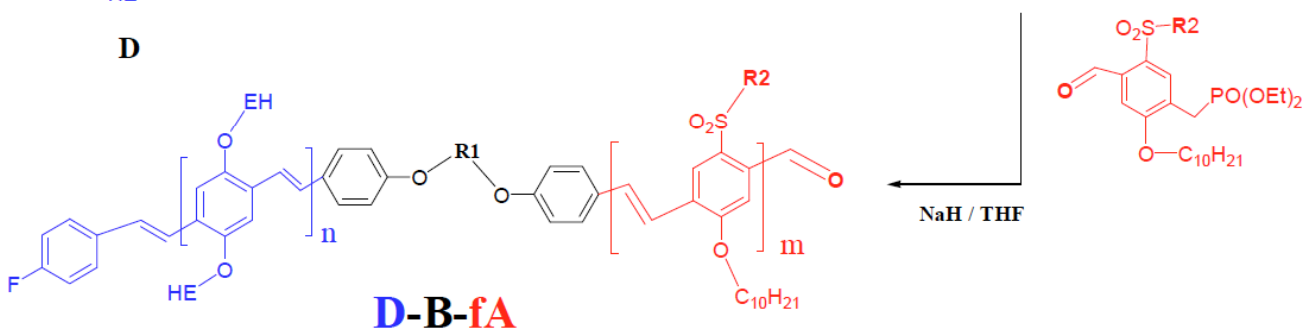

EH= 2-ethylhexyl

$\mathrm{R} 2=-\mathrm{CH}_{2}-\mathrm{CH}_{2}-\mathrm{C}_{8} \mathrm{~F}_{17}$

$\mathrm{R} 1=\left(-\mathrm{CH}_{2}-\right)_{\mathrm{p}}$

Scheme 3: Synthetic scheme of the DB and the DBfA block copolymer.

1): $\delta(\mathrm{ppm}) 2.34(\mathrm{~m}, 2 \mathrm{H}), 2.99(\mathrm{t}, \mathrm{J}=8.66 \mathrm{~Hz}, 2 \mathrm{H}), 5.07$ (s, $1 \mathrm{H}, \mathrm{OH}), 6.82(\mathrm{~d}, \mathrm{~J}=8.18 \mathrm{~Hz}, 2 \mathrm{H}), 7.35(\mathrm{~d}, \mathrm{~J}=7.96$, 2H). ${ }^{13} \mathrm{C}$ NMR $\left(\mathrm{CDCl}_{3}\right): \delta(\mathrm{ppm}) 26.97,31.92,32.23$, $32.52,116.62,125.06,134.46,155.89$.

\section{1-decyloxy-4-(1H, 1H, 2H, 2H-perflourodecylsulfanyl) benzene (3)}

To a 250-ml two-neck round-bottom flask was added 2 (10.7g, $0.0187 \mathrm{~mol}), 1$-bromodecane $(4.55 \mathrm{~g}$, $0.0206 \mathrm{~mol}$ ), anhydrous dimethylsulfoxide (DMSO, 100 $\mathrm{ml}$ ). $5 \mathrm{~mL}$ of $50 \% \mathrm{NaOH}$ was drop-wised in the mixture at $70^{\circ} \mathrm{C}$, and the mixture was stirred at $88^{\circ} \mathrm{C}$ for $1.5 \mathrm{~h}$. The mixture was cooled to room temperature and diluted by $100-\mathrm{ml}$ of water, added $10-\mathrm{ml}$ of $2 \mathrm{~N} \mathrm{HCl}$, extracted with $400-\mathrm{ml}$ hexane. The hexane extract was dried with $\mathrm{MgSO}_{4}$ and filtered. The crude product was purified by column chromatography with silica gel and (1:6, ethylacetate: hexanes) to give $12.4 \mathrm{~g}$ of yellow solid product. Yield: $93 \%$. ${ }^{1} \mathrm{H}$ NMR $\left(\mathrm{CDCl}_{3}\right.$, also see Figure 1): $\delta(\mathrm{ppm}) 0.88(\mathrm{t}, \mathrm{J}=5.46 \mathrm{~Hz}, 3 \mathrm{H}), 1.00-1.60(\mathrm{~m}$, $14 \mathrm{H}$ ), 1.78 (quintet, J=7.84 Hz, 2H), $2.35(\mathrm{~m}, 2 \mathrm{H}), 2.98$ (t, J=8.66 Hz, 2H), 3.94 (t, J=6.59Hz, 2H), 6.87 (d, $\mathrm{J}=9.42 \mathrm{~Hz}, 2 \mathrm{H}), 7.37(\mathrm{~d}, \mathrm{~J}=8.10 \mathrm{~Hz}, 2 \mathrm{H}) .{ }^{13} \mathrm{C} N \mathrm{NMR}$ $\left(\mathrm{CDCl}_{3}\right): \delta(\mathrm{ppm}) 22.81,26.17,26.93,29.34,29.48$, $29.53,29.73,32.05,68.37,116.34,123.85,134.25$, 159.44 .

\section{2-bromomethyl-1-decyloxy-4-(1H, 1H, 2H, 2H- perflourodecylsulfanyl)benzene (4, an intermediate)}

A mixture of 1-decyloxy-4- $(1 \mathrm{H}, 1 \mathrm{H}, 2 \mathrm{H}, 2 \mathrm{H}$ perflourodecylsulfanyl)benzene $3(29.4 \mathrm{~g}, 0.0413 \mathrm{~mol})$, paraformaldehyde $(5.21 \mathrm{~g}, 0.174 \mathrm{~mol})$, glacial acetic acid $(31 \mathrm{~g})$, acetic acid anhydride $(15.6 \mathrm{~g})$, and $33 \%$ $\mathrm{HBr} / \mathrm{HOAc}(48 \mathrm{~g})$ in $250 \mathrm{ml}$ round bottom flask was stirred at $92{ }^{\circ} \mathrm{C}$ for $19.5 \mathrm{~h}$. The reaction mixture was cooled to room temperature, diluted by $100-\mathrm{ml}$ of water, added $20-\mathrm{ml}$ of $10 \% \mathrm{NaOH}$, and extracted with $800-\mathrm{ml}$ hexane. The hexane extract was dried with $\mathrm{MgSO}_{4}$, filtered, and condensed to give $35.5 \mathrm{~g}$ brown oil which was used for the next step without purification.

(2-decyloxy-5-(1H, 1H, 2H, 2H-perflourodecylsulfanyl)-benzyl)-phosphonic acid diethyl ester (5)

To a 250-ml two-neck round-bottom flask was added all 2-bromomethyl-1-decyloxy-4- $(1 \mathrm{H}, 1 \mathrm{H}, 2 \mathrm{H}$, $2 \mathrm{H}$-perflourodecylsulfanyl)benzene $4(35.5 \mathrm{~g})$ in a nitrogen atmosphere for five minutes. $11.5 \mathrm{~mL}$ of triethyl phosphite was dropped into the mixture, and the mixture was stirred at $135{ }^{\circ} \mathrm{C}$ for 16 hours. After the remaining triethyl phosphite was removed, the crude product was purified by column chromatography with silica gel and (1:2 ethylacetate: hexanes) to give $22.5 \mathrm{~g}$ of yellow oil product. Yield: $63.5 \%$. ${ }^{1} \mathrm{H} \mathrm{NMR}\left(\mathrm{CDCl}_{3}\right.$, also see Figure 1): $\delta(\mathrm{ppm}) 0.88(\mathrm{t}, \mathrm{J}=5.28 \mathrm{~Hz}, 3 \mathrm{H})$, 1.00-1.50 (m, 20H), 1.78 (quintet, J=7.54 Hz, 2H), 2.37 (m, 2H), 2.99 (t, J=8.66 Hz, 2H), 3.29 (d, J=21.85 Hz, $2 \mathrm{H}), 4.05(\mathrm{~m}, 6 \mathrm{H}), 6.84(\mathrm{~d}, \mathrm{~J}=8.48 \mathrm{~Hz}, 1 \mathrm{H}), 7.31(\mathrm{~d}$, $\mathrm{J}=7.91 \mathrm{~Hz}, 1 \mathrm{H}), 7.47(\mathrm{~s}, 1 \mathrm{H}) .{ }^{13} \mathrm{C}$ NMR $\left(\mathrm{CDCl}_{3}\right): \delta(\mathrm{ppm})$ $14.21,16.46,16.54,22.98,25.83,26.49,27.09,27.77$, $29.62,29.94,32.24,62.08,68.84,111.76,122.30$, 124.25, 133.03, 135.94, 157.27. Anal. Calc.: C, 43.16; H 4.67; F, 37.44; S, 3.72. Found: C, 43.43; H 4.64; F, $37.18 ; \mathrm{S}, 3.63$.

(4-bromomethyl-2-decyloxy-5-(1H, 1H, 2H, 2Hperflourodecylsulfanyl)-benzyl)-phosphonic acid diethyl ester (6, an intermediate)

A mixture of (2-decyloxy-5- $(1 \mathrm{H}, 1 \mathrm{H}, 2 \mathrm{H}, 2 \mathrm{H}-$ perflourodecylsulfanyl)-benzyl)-phosphonic acid diethyl ester $5(5.5 \mathrm{~g}, 6.37 \mathrm{mmol})$, paraformaldehyde $(3.0 \mathrm{~g}$, $100 \mathrm{mmol})$, trifluoroacetic acid $(28 \mathrm{ml})$, trifluoroacetic acid anhydride $(5.5 \mathrm{~g})$, and 33\% $\mathrm{HBr} / \mathrm{HOAc}(5.5 \mathrm{~g})$ in 
$150 \mathrm{ml}$ round bottom flask was stirred at $65{ }^{\circ} \mathrm{C}$ for 5 hours. The reaction mixture was cooled to room temperature, diluted by $40-\mathrm{ml}$ of water, added $5-\mathrm{ml}$ of $10 \% \mathrm{NaOH}$, and extracted with $40-\mathrm{ml}$ hexane. The hexane extract was dried with $\mathrm{MgSO}_{4}$, filtered, and condensed to give $8.0 \mathrm{~g}$ brown oil which was used for the next step without purification.

\section{(2-decyloxy-5-(1H, 1H, 2H, 2H-perflourodecylsul- fanyl)-4-hydroxymethyl-benzyl)-phosphonic acid diethyl ester (7)}

A vigorously stirred mixture of the crude (4bromomethyl-2-decyloxy-5-(1H, $1 \mathrm{H}, 2 \mathrm{H}, 2 \mathrm{H}$-perflourodecylsulfanyl)-benzyl)-phosphonic acid diethyl ester 6 $(8.0 \mathrm{~g})$, sodium bicarbonate $(2.9 \mathrm{~g})$, 1-methylpyrolidinone (NMP) $(58.5 \mathrm{~g})$, and $16.0 \mathrm{~g}$ of water in 150 $\mathrm{ml}$ round bottom flask was stirred at $90{ }^{\circ} \mathrm{C}$ for $3.5 \mathrm{~h}$. The mixture was cooled to room temperature and diluted by $50-\mathrm{ml}$ of water, added $2.0-\mathrm{ml}$ of $2 \mathrm{~N} \mathrm{HCl}$, extracted with $100-\mathrm{ml}$ hexane. The hexane extract was dried with $\mathrm{MgSO}_{4}$ and filtered. The crude product was purified by column chromatography with silica gel and $\mathrm{CH}_{3} \mathrm{COOC}_{2} \mathrm{H}_{5}$ to give $4.4 \mathrm{~g}$ of yellow solid product. Yield: $77 \%$. ${ }^{1} \mathrm{H}$ NMR $\left(\mathrm{CDCl}_{3}\right.$, also see Figure 1): $\delta(\mathrm{ppm}) 0.88(\mathrm{t}, \mathrm{J}=5.28 \mathrm{~Hz}, 3 \mathrm{H}), 1.00-1.70(\mathrm{~m}, 20 \mathrm{H})$, 1.78 (quintet, $\mathrm{J}=7.54 \mathrm{~Hz}, 2 \mathrm{H}), 2.37(\mathrm{~m}, 2 \mathrm{H}), 3.05(\mathrm{t}$, $\mathrm{J}=8.66 \mathrm{~Hz}, 2 \mathrm{H}), 3.35(\mathrm{~d}, \mathrm{~J}=21.85 \mathrm{~Hz}, 2 \mathrm{H}), 4.05(\mathrm{~m}, 6 \mathrm{H})$, 4.80 (s, 2H), 7.05 (s, J=8.48 Hz, 1H), 7.45 (s, J=7.91 $\mathrm{Hz}, 1 \mathrm{H}) .{ }^{13} \mathrm{C}$ NMR $\left(\mathrm{CDCl}_{3}\right): \delta(\mathrm{ppm}) 14.62,16.85,23.23$, 25.26, 26.70, 27.33, 29.90, 30.15, 32.45, 62.50, 63.94, 69.12, 112.63, 121.03, 122.04, 137.32, 144.20, 157.83.Anal. Calc.: C, 43.05; H, 4.74; F, 36.18; S, 3.59.Found:C, 43.23; H, 4.86; F, 35.93; S, 3.49

[5-(1H, 1H, 2H, 2H-perflourodecyl-1-sulfonyl)-2decyloxy-4-hydroxymethyl-benzyl]-phosphonic acid diethyl ester (8, an intermediate)

A mixture of 2-decyloxy-5- $(1 \mathrm{H}, 1 \mathrm{H}, 2 \mathrm{H}, 2 \mathrm{H}$ perflourodecylsulfanyl)-4-hydroxymethyl-benzyl)-phosphonic acid diethyl ester 7 , glacial acetic acid $(4.0 \mathrm{ml})$ and $50 \%$ of $\mathrm{H}_{2} \mathrm{O}_{2}(1.6 \mathrm{~g})$ in $150 \mathrm{ml}$ round bottom flask was stirred at room temperature for twenty minutes, then at $90^{\circ} \mathrm{C}$ for 45 minutes. The excess glacial acetic acid and $\mathrm{H}_{2} \mathrm{O}_{2}$ were removed under 100 mbar at $90^{\circ} \mathrm{C}$ for ten minutes. The mixture was cooled to room temperature, $50 \% \mathrm{NaOH}(3 \mathrm{ml})$ was added, then product was extracted by $80-\mathrm{ml}$ ether. The ether extract was dried with $\mathrm{MgSO}_{4}$, filtered, and condensed to give $4.5 \mathrm{~g}$ of crude products (mixture of 8 and $8 \mathrm{a}$ ) that were subsequently treated by a mixture of $\mathrm{KOH}(2.0 \mathrm{~g})$, water $(4.0 \mathrm{~g})$, and ethanol $(25-\mathrm{ml})$ at room temperature for three minutes. After adding $\mathrm{NaHCO}_{3}(4.5 \mathrm{~g})$, the mixture was stirred for five minutes, condensed on a rotary evaporator in $40^{\circ} \mathrm{C}$ water bath under reduced pressure. The residue was extracted by ether, dried with $\mathrm{MgSO}_{4}$, and condensed to give of $4.35 \mathrm{~g}$ yellow solid crude product 8 which was pure enough to be used in the next step.

[5-(1H, 1H, 2H, 2H-perflourodecyl-1-sulfonyl)-2decyloxy-4-formyl-benzyl]-phosphonic acid diethyl ester (acceptor monomer 9)

A mixture of $[5-(1 \mathrm{H}, 1 \mathrm{H}, 2 \mathrm{H}, 2 \mathrm{H}$-perflourodecyl-1sulfonyl)-2-decyloxy-4-hydroxymethyl-benzyl]-phosphonic acid diethyl ester $8(5.43 \mathrm{~g})$, methylene chloride (40$\mathrm{ml}$ ) and pyridinum chlorochromate (PCC) $(9.4 \mathrm{~g})$ in 250 $\mathrm{ml}$ round bottom flask was stirred at room temperature for four hours. The mixture was diluted by water (100$\mathrm{ml})$, dichloromethane $(50 \mathrm{ml})$, and extracted with hexane $(500-\mathrm{ml})$. The hexane extract was dried by $\mathrm{MgSO}_{4}$, filtered, and condensed to give of $4.53 \mathrm{~g}$ crude product which was further purified by column chromatography using silica gel and an elution solvent mixture $(1: 2$, ethylacetate/hexanes) to give $3.34 \mathrm{~g}$ of white solid product. Yield: $62 \%$. ${ }^{1} \mathrm{H}$ NMR $\left(\mathrm{CDCl}_{3}\right.$, also shown in Figures 1 and 2): $\delta(p p m) 0.88(\mathrm{t}, J=6.78 \mathrm{hz}$, $3 \mathrm{H}$ ), $1.00-1.70(\mathrm{~m}, 20 \mathrm{H}), 1.88$ (quintet, $\mathrm{J}=6.59 \mathrm{~Hz}, 2 \mathrm{H}$ ), $2.69(\mathrm{~m}, 2 \mathrm{H}), 3.39(\mathrm{~d}, \mathrm{~J}=21.66 \mathrm{hz}, 2 \mathrm{H}), 3.50(\mathrm{t}, \mathrm{J}=7.91$ $\mathrm{Hz}, 2 \mathrm{H})$, , $4.12(\mathrm{~m}, 6 \mathrm{H}), 7.55(\mathrm{~s}, 1 \mathrm{H}), 8.05(\mathrm{~s}, 1 \mathrm{H}), 10.71$ (s, $1 \mathrm{H},-\mathrm{CHO}) \cdot{ }^{13} \mathrm{C} \mathrm{NMR}\left(\mathrm{CDCl}_{3}\right.$, also shown in Figure 3): $\delta(\mathrm{ppm}) 14.17,16.34,16.42,22.77,25.13,26.15$, 28.13, 29.07, 29.44, 29.64, 31.99, 50.02, 62.42, 69.79, $111.93,127.70,130.18,134.00,135.63,161.02$, 188.78. Anal. Calc.: C, 41.66; H 4.37; F, 35.00; S, 3.48 . Found: C, 41.57; H 4.35; F, 35.09; S, 3.32.

\section{2-Bromomethyl-1,4-bis-(2-ethyl-hexyloxy)-benzene (11, an intermediate)}

A slightly modified procedure from [14] was used here. A mixture of 1,4-bis-(2-ethyl-hexyloxy)-benzene 10 [14] (19.00g, $0.0567 \mathrm{~mol})$, paraformaldehyde $(2.04 \mathrm{~g}$, $0.0683 \mathrm{~mol})$, glacial acetic acid $(41.0 \mathrm{~g})$ and $30 \%$ $\mathrm{HBr} / \mathrm{HOAc}(31.0 \mathrm{~mL})$ in $250 \mathrm{ml}$ round bottom flask was stirred at $60{ }^{\circ} \mathrm{C}$ for 4 hours. The mixture was extracted by hexane $(300 \mathrm{ml})$ and washed with a mixture of water $(100 \mathrm{ml})$ and saturated sodium bicarbonate $(10 \mathrm{ml})$. The hexane extraction was dried with magnesium sulfate and condensed to afford $23.5 \mathrm{~g}$ crude product, and this crude product is used in the next step without purification.

\section{[2,5-Bis-(2-ethyl-hexyloxy)-benzyl]-phosphonic acid diethyl ester (12)}

A mixture of 11 crude product $(23.50 \mathrm{~g}, 0.0553 \mathrm{~mol})$ and triethyl phosphite $(12.86 \mathrm{~g}, 0.0774 \mathrm{~mol})$ in $150 \mathrm{ml}$ round bottom flask was stirred at $140{ }^{\circ} \mathrm{C}$ oil bath for 3.0 


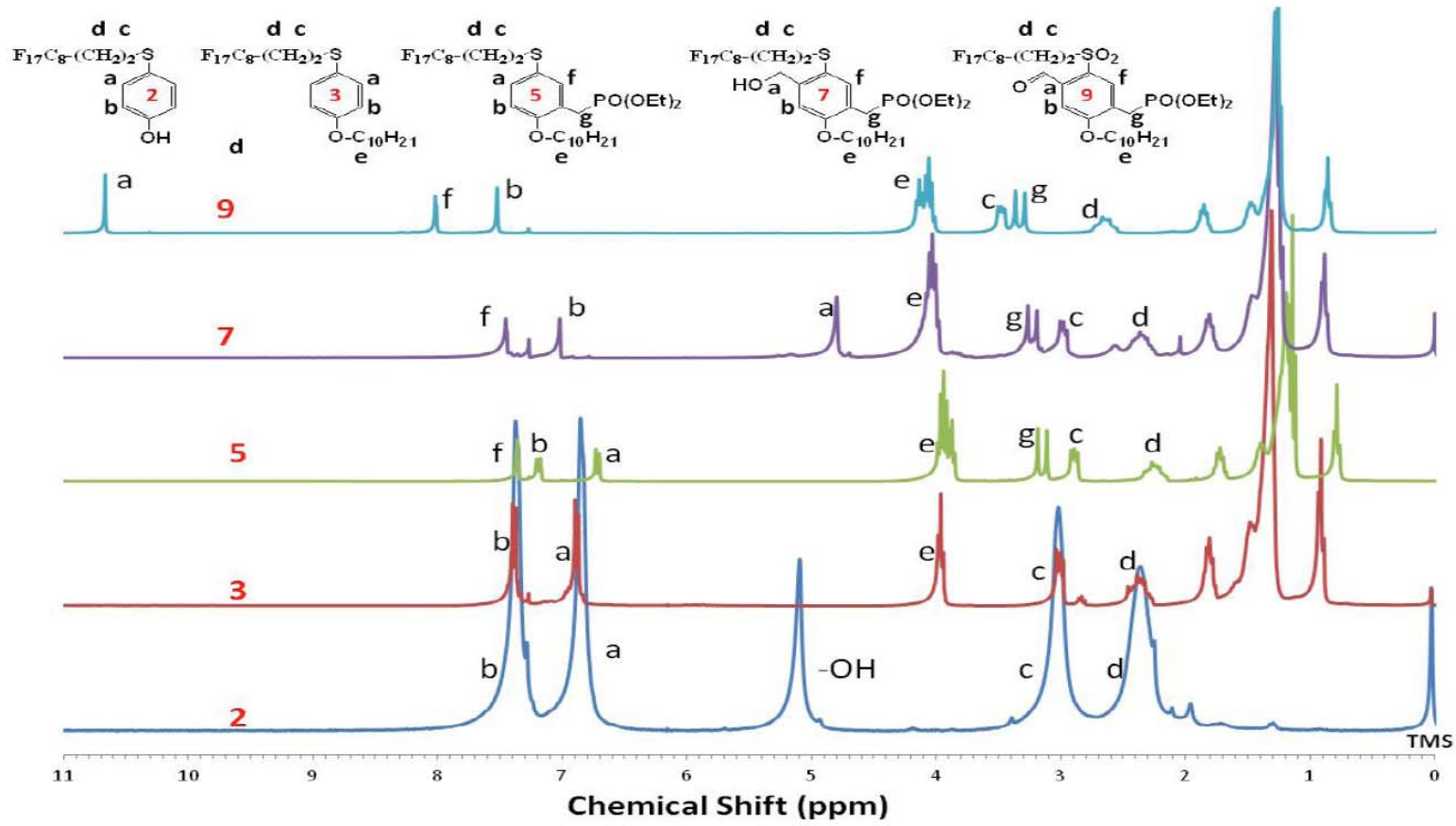

Figure 1: ${ }^{1} \mathrm{H}$ NMR spectra of intermediate compounds and the acceptor monomer 9.

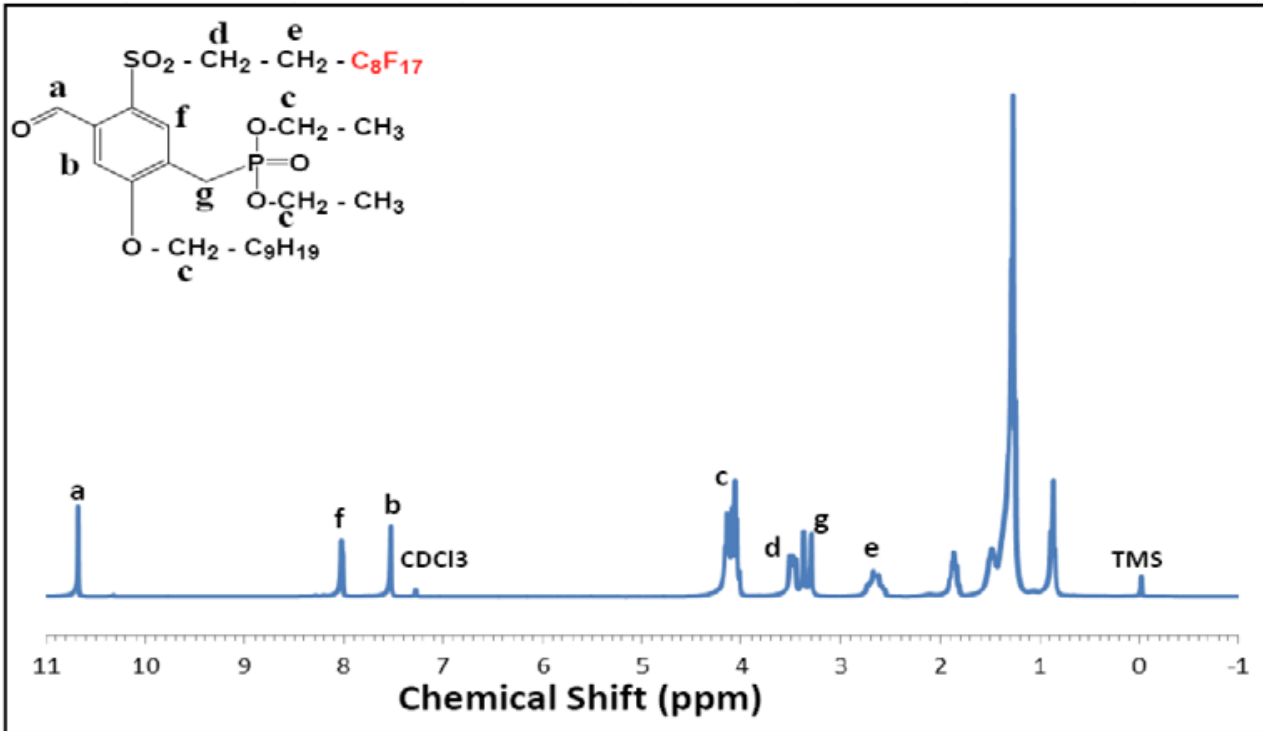

Figure 2: ${ }^{1} \mathrm{H}-\mathrm{NMR}$ spectrum of $[5-(1 \mathrm{H}, 1 \mathrm{H}, 2 \mathrm{H}, 2 \mathrm{H}$-perflourodecyl-1-sulfonyl)-2-decyloxy-4-formyl-benzyl]-phosphonic acid diethyl ester (acceptor monomer 9).

hours. The remaining triethyl phosphite was removed by vacuum distillation at $150{ }^{\circ} \mathrm{C}$, and the residue was purified with a silica gel column using 1:4 (Ethylacetate/ Hexanes) as the eluent to afford $14.5 \mathrm{~g}$ colorless oil. Yield: $53 \%$. ${ }^{1} \mathrm{H}$ NMR $\left(\mathrm{CDCl}_{3}\right)$ : $\delta(\mathrm{ppm}) 0.89$ (t, J=4.25 $\mathrm{hz}, 18 \mathrm{H}), 1.00-2.0(\mathrm{~m}, 18 \mathrm{H}), 3.27(\mathrm{~d}, \mathrm{~J}=22.23 \mathrm{hz}, 2 \mathrm{H})$, 3.78 (t, J=4.95 Hz, 2H), 4.02 (quitet, $\mathrm{J}=7.50 \mathrm{hz}, 4 \mathrm{H}$ ), $6.75(\mathrm{~d}, 2 \mathrm{H}), 6.95(\mathrm{~s}, 1 \mathrm{H}) .{ }^{13} \mathrm{C} \mathrm{NMR}\left(\mathrm{CDCl}_{3}\right): \delta(\mathrm{ppm})$ 11.03, 14.11, 16.27, 23.04, 23.83, 25.49, 27.34, 29.06, $30.58,39.45,61.04,70.68,112.36,113.65,117.38$,
121.0, 150.86, 152.96.Anal. Calc.: C, 66.91; H, 10.19. Found: $\mathrm{C}, 66.81 ; \mathrm{H}, 10.09$.

\section{[2,5-Bis-(2-ethyl-hexyloxy)-4-formyl-benzyl]- phosphonic acid diethyl ester (13)}

To a 250-ml two-neck round-bottom flask was added [2,5-bis-(2-ethyl-hexyloxy)-benzyl]-phosphonic acid diethyl ester $12(4.33 \mathrm{~g}, 8.93 \mathrm{mmol})$ and methylene choride $(27.0 \mathrm{~mL})$. The solution mixture was cooled in an ice bath for 5 minutes, and a mixture of a- 


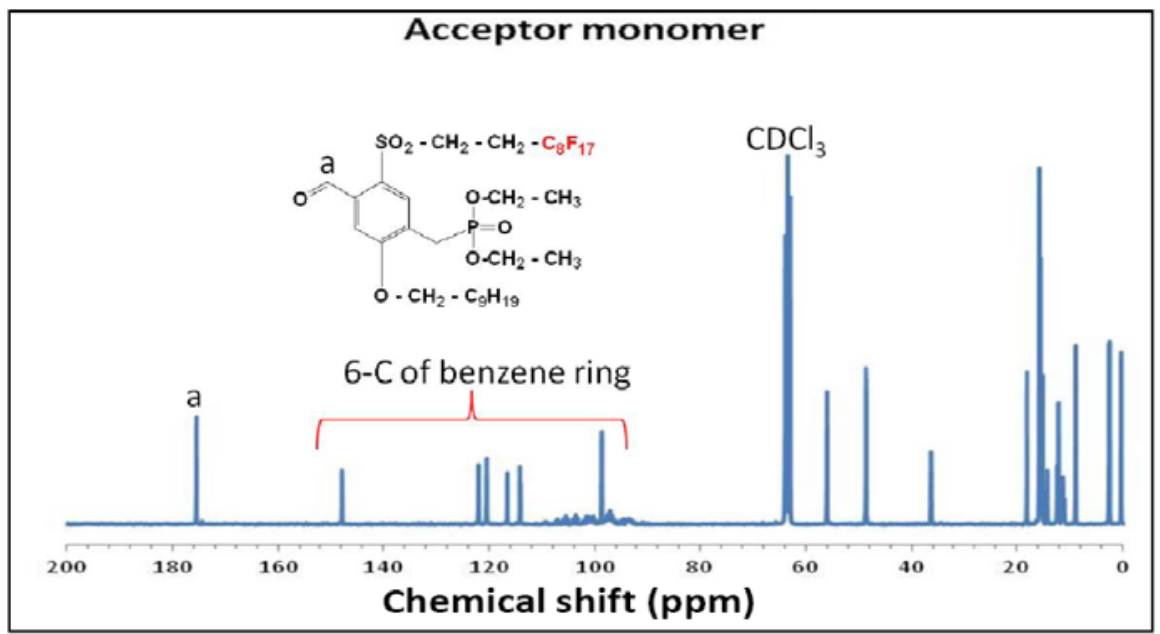

Figure 3: ${ }^{13} \mathrm{C}-\mathrm{NMR}$ spectrum of $[5-(1 \mathrm{H}, 1 \mathrm{H}, 2 \mathrm{H}, 2 \mathrm{H}$-perflourodecyl-1-sulfonyl)-2-decyloxy-4-formyl-benzyl]-phosphonic acid diethyl ester (acceptor monomer 9).

dichloromethyl methyl ether $(1.23 \mathrm{~g}, 10.71 \mathrm{mmol})$ and titanium tetrachloride $(5.93 \mathrm{~g}, 31.25 \mathrm{mmol})$ was added dropwise into the cool mixture over 2 minutes. The color of solution mixture was changed to dark red instantly and a mixture was continued to stir for one more hour. The reaction mixture was poured into a stirred mixture of $\mathrm{K}_{2} \mathrm{CO}_{3}(7.52 \mathrm{~g})$, water $(200 \mathrm{~mL})$ and ice $(50 \mathrm{~g})$. The crude product was extracted by $200 \mathrm{~mL}$ hexanes and purified with a silica gel column using 1:2 (Ethylacetate/Hexanes) as the eluent to afford $4.20 \mathrm{~g}$ light yellow oil pure product. Yield: $92 \% .{ }^{1} \mathrm{H}$ NMR $\left(\mathrm{CDCl}_{3}\right.$, also shown in Figure 4): $\delta$ (ppm) $0.89-1.74$ $(\mathrm{m}, 36 \mathrm{H}), 3.33(\mathrm{~d}, \mathrm{~J}=22.23 \mathrm{hz}, 2 \mathrm{H}), 3.85(\mathrm{t}, \mathrm{J}=5.28 \mathrm{~Hz}$, $2 \mathrm{H}$ ), 3.93 (t, J=4.71 Hz, 2H), 4.04 (quitet, $\mathrm{J}=4.71 \mathrm{hz}$,
4H), $7.09(\mathrm{~s}, 1 \mathrm{H}), 7.29(\mathrm{~s}, 1 \mathrm{H}), 10.45(\mathrm{~s}, 1 \mathrm{H},-\mathrm{CHO})$. ${ }^{13} \mathrm{C}$ NMR $(\mathrm{CDCl} 3): \delta(\mathrm{ppm}) 11.19,14.06,16.34,23.05$, 23.91, 26.15, 27.97, 29.08, 30.62, 39.55, 62.06, 71.40, $108.88,116.00,123.88,129.47,150.77,156.06$, 189.39. Anal. Calc.: C, 65.60; H 9.63. Found: C, 66.37; H 9.74 .

\section{The Fluorinated Acceptor Block (fA)}

To a solution of 9 (500 mg, $0.6289 \mathrm{mmol})$, 4-fluorobenzyl)-phosphonic acid diethyl ester $(7.80 \mathrm{mg}, 0.0314$ $\mathrm{mmol}$ ) and $5.0 \mathrm{~mL}$ of THF in $16 \mathrm{ml}$ vial in a glove box was added $\mathrm{NaH}(18.11 \mathrm{mg}, 0.7547 \mathrm{mmol}$ in $4.0 \mathrm{~mL}$ of THF) over two minutes. The mixture was stirred for 10 more minutes, neutralized with 5 drops of the mixture

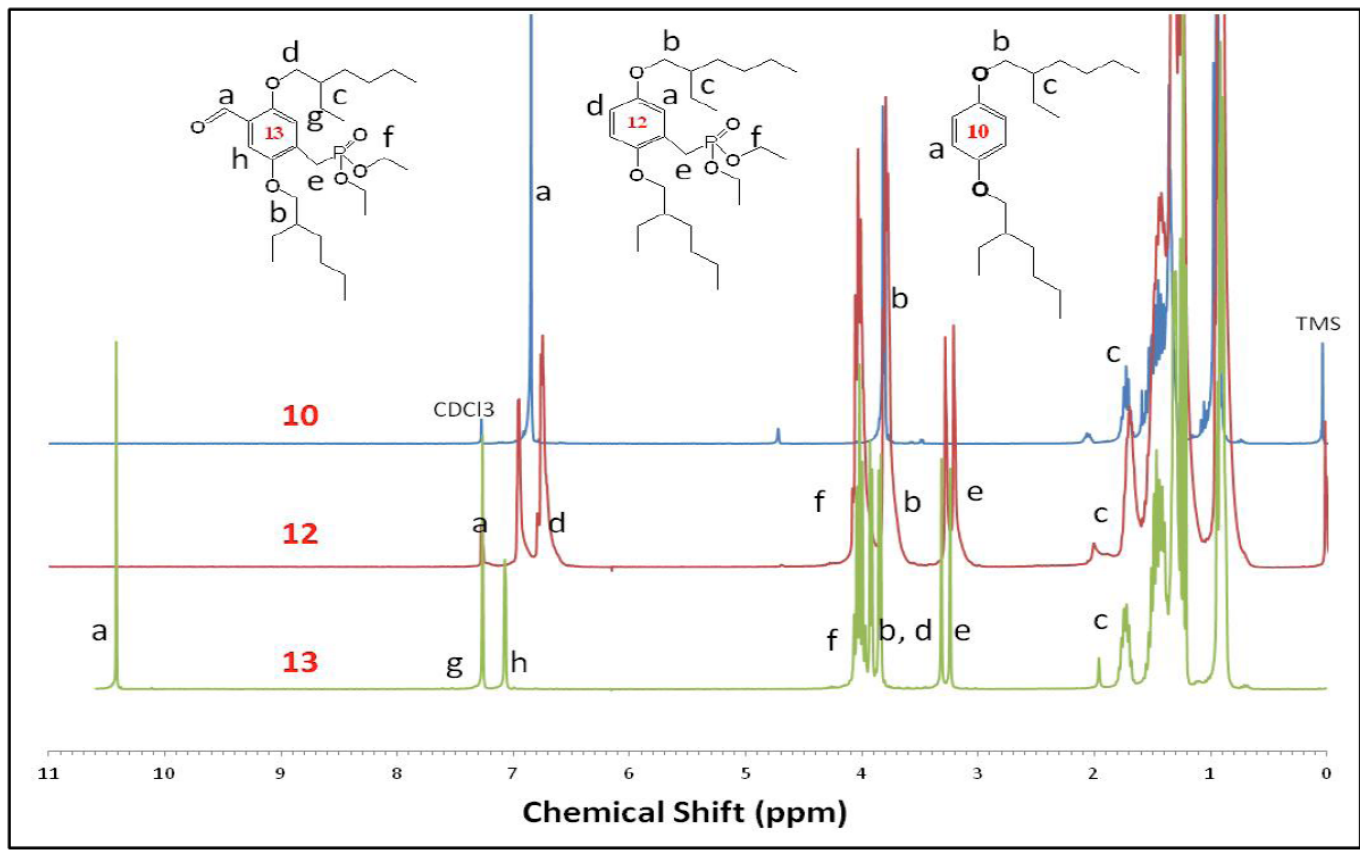

Figure 4: ${ }^{1} \mathrm{H}-\mathrm{NMR}$ spectra of intermediate compounds and donor monomer 13. 


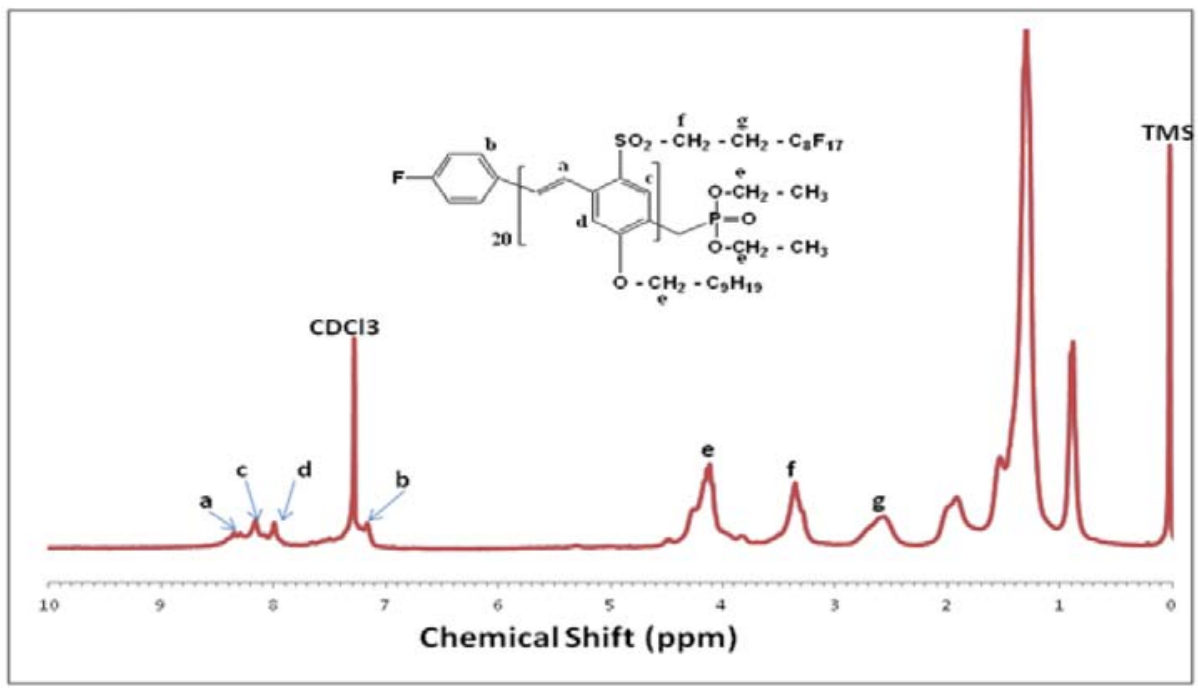

Figure 5: ${ }^{1} \mathrm{H}-\mathrm{NMR}$ spectrum of fluorinated acceptor block $\mathbf{f A}$.

of acetic acid and methanol (50\%), and dropped into the stirred methanol $(150 \mathrm{~mL})$. Dark orange polymer solid (350 mg) was filtrated and dried at $60{ }^{\circ} \mathrm{C}$ in vacuum for two days. Yield: $71.5 \%$. ${ }^{1} \mathrm{H}$ NMR $\left(\mathrm{CDCl}_{3}\right.$, also shown in Figure 5): $\delta(\mathrm{ppm}) 0.85$ (t, $\mathrm{J}=5.65 \mathrm{~Hz}$, $9 \mathrm{H}), 1.35-2.15(\mathrm{~m}, 20 \mathrm{H}), 2.60(\mathrm{~m}, 2 \mathrm{H}), 3.35$ (t, J=8.55 $\mathrm{Hz}, 2 \mathrm{H}), 4.10$ (t, J=4.15 Hz, 6H), 7.10 (s, 2H), 7.95 (s, $1 \mathrm{H}), 8.20(\mathrm{~s}, 1 \mathrm{H}), 8.35(\mathrm{~d}, \mathrm{~J}=5.60 \mathrm{~Hz}), 1 \mathrm{H}) .{ }^{13} \mathrm{C} N M R$ $\left(\mathrm{CDCl}_{3}\right): \delta(\mathrm{ppm})$ 10.42, 12.98, 19.27, 22.77, 25.95, 26.24, 28.54, 44.6, 58.88, 65.95, 68.28, 107.8, 111.1, $115.4,124.4,130.0,158.0$.

\section{The Donor Block (D)}

To a solution of $13(2.26 \mathrm{mmol}, 1.158 \mathrm{~g})$, 4-fluorobenzyl)-phosphonic acid diethyl ester $(27.80 \mathrm{mg}, 0.113$ $\mathrm{mmol}$ ) and $10.0 \mathrm{~mL}$ of THF in $50.0 \mathrm{ml}$ vial in a glove box was added t-BuOK $(380.5 \mathrm{mg}, 3.39 \mathrm{mmol}$ in 6.0 $\mathrm{mL}$ of THF) over two minutes. The mixture was stirred for 5 more minutes and dropped into the stirred methanol $(150 \mathrm{~mL})$. Dark red polymer solid $(721 \mathrm{mg})$ was collected by filtration and dried at $60^{\circ} \mathrm{C}$ in vacuum for two days. Yield: $88.8 \%$. ${ }^{1} \mathrm{H} \mathrm{NMR}\left(\mathrm{CDCl}_{3}\right.$, also shown in Figure 6): $\delta(\mathrm{ppm})$ 0.85-1.82 $(\mathrm{m}, 38 \mathrm{H}), 3.29$ (d, J=20.91 Hz, 2H), 3.47 (s, 4H), 3.95 (s, 4H), 6.84 (d, $\mathrm{J}=21.48 \mathrm{hz}, 2 \mathrm{H}), 7.19(\mathrm{~s}, 1 \mathrm{H}), 7.52(\mathrm{~s}, 1 \mathrm{H}) .{ }^{13} \mathrm{C} \mathrm{NMR}$ $\left(\mathrm{CDCl}_{3}\right): \delta(\mathrm{ppm}) 11.35,14.11,23.11,24.34,29.16$, 30.85, 39.84, 71.57, 109.38, 122.05, 127.32, 151, 160.

\section{The Donor-Bridge Block (DB)}

To a $50.0 \mathrm{ml}$ of ground bottom flask was added the donor block $\mathbf{D}(300 \mathrm{mg})$, the bridge $\mathbf{B}(115 \mathrm{mg}$, in large excess over D), and THF (5.0 $\mathrm{ml})$ in the chemical glove box. The mixture was heated until fully dissolved. After being cooled for 5 minutes, the mixture was continued to add t-BuOK $(27 \mathrm{mg})$ in THF $(1 \mathrm{~mL})$ over 20 seconds.
The mixture was continued to stir for one more minute. The mixture was quenched by $0.1 \mathrm{~mL}$ of $30 \%$ acetic acid and dropped into the stirred methanol (100 mL). The polymer product was collected by filtration and dried at $60{ }^{\circ} \mathrm{C}$ in vacuum for two days. Yield: 250 $\mathrm{mg} .{ }^{1} \mathrm{H}$ NMR $\left(\mathrm{CDCl}_{3}\right.$, also shown in Figure 6): $\delta(\mathrm{ppm})$ 0.85-1.82 (m, $38 \mathrm{H}), 3.47(\mathrm{~s}, 4 \mathrm{H}), 3.95(\mathrm{~s}, 4 \mathrm{H}), 6.84(\mathrm{~d}$, $\mathrm{J}=21.48 \mathrm{hz}, 2 \mathrm{H}), 7.19$ (s, 1H), $7.52(\mathrm{~s}, 1 \mathrm{H}), 7.85$ (s, $4 \mathrm{H}), 9.90(\mathrm{~s}, 1 \mathrm{H}) .{ }^{13} \mathrm{C}$ NMR $(\mathrm{CDCl} 3): \delta(\mathrm{ppm}) 12.25$, $14.5,23.5,24.5,28.5,32.0,40.0,72.50,109.0,125.5$, $127.5,152.5$.

\section{The Final Block Copolymer (DBfA)}

To a solution of DB $(94.0 \mathrm{mg}, 0.0134 \mathrm{mmol})$, monomer 9 (260 mg, $0.282 \mathrm{mmol})$ and $2.0 \mathrm{~mL}$ of THF in $50 \mathrm{ml}$ ground bottom flash in a glove box was added $\mathrm{NaH}(11.0 \mathrm{mg}, 0.458 \mathrm{mmol}$ in $2.0 \mathrm{~mL}$ of THF) over two minutes. The mixture was continued to stir for five more minutes, and was dropped into a stirred methanol (60 $\mathrm{mL}$ ). Dark red polymer solid $(180 \mathrm{mg}$ ) was collected by filtration and dried at $60{ }^{\circ} \mathrm{C}$ in vacuum for two days. Yield: $120 \mathrm{mg} .{ }^{1} \mathrm{H}$ NMR $\left(\mathrm{CDCl}_{3}\right.$, also shown in Figure 6): $\delta(\mathrm{ppm})$ 0.85-1.82 (m, $38 \mathrm{H}), 2.50(\mathrm{~s}, 2 \mathrm{H}), 3.30(\mathrm{~s}$, $2 \mathrm{H}), 3.50(\mathrm{~s}, 4 \mathrm{H}), 3.90(\mathrm{~s}, 4 \mathrm{H}), 6.80(\mathrm{~d}, \mathrm{~J}=21.48 \mathrm{hz}$, 2H), $7.12(\mathrm{~s}, 1 \mathrm{H}), 7.50(\mathrm{~s}, 1 \mathrm{H}), 7.85(\mathrm{~s}, 4 \mathrm{H}), 8.25(\mathrm{~d}, \mathrm{~J}=$ $25.5 \mathrm{~Hz}, 2 \mathrm{H}), 9.85(\mathrm{~s}, 1 \mathrm{H}) .{ }^{13} \mathrm{C} \mathrm{NMR}(\mathrm{CDCl} 3$, also shown in Figure 7): $\delta$ (ppm) 10.0, 13.5, 22.5, 24.5, $28.5,30.10,39.5,72.5,109.0,114.0,122.5,127.5$, 132.0, 150.0, 160.0.

\section{RESULTS AND DISCUSSION}

\subsection{Materials Synthesis and NMR Studies}

The final fluorinated DBfA block copolymer is designed and prepared in three key synthetic steps. 


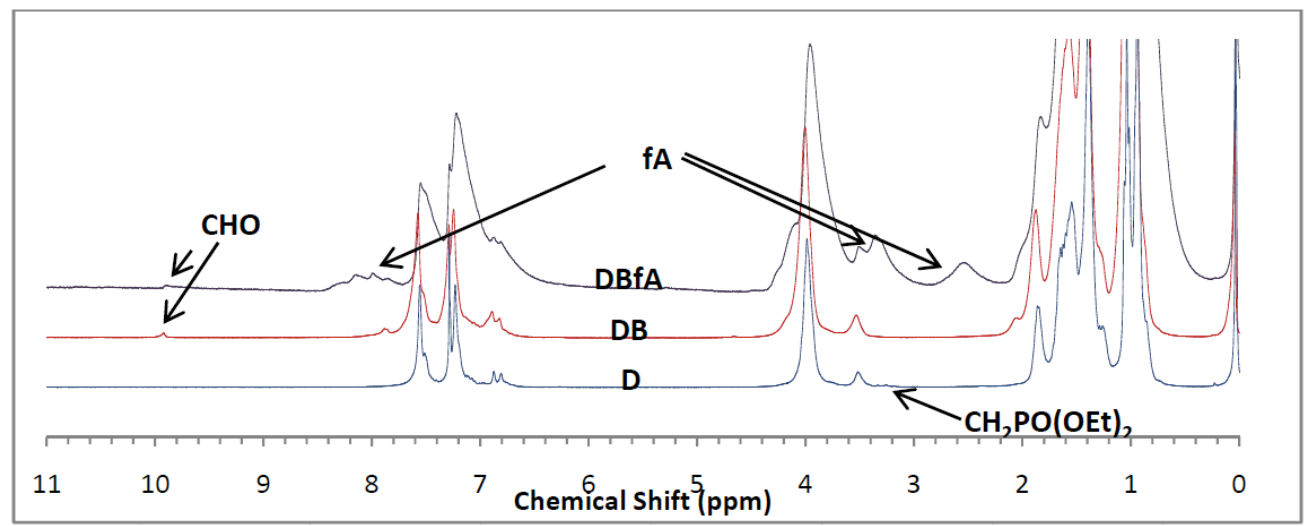

Figure 6: ${ }^{1} \mathrm{H}-\mathrm{NMR}$ spectra of $\mathbf{D}, \mathrm{DB}$, and DBfA.

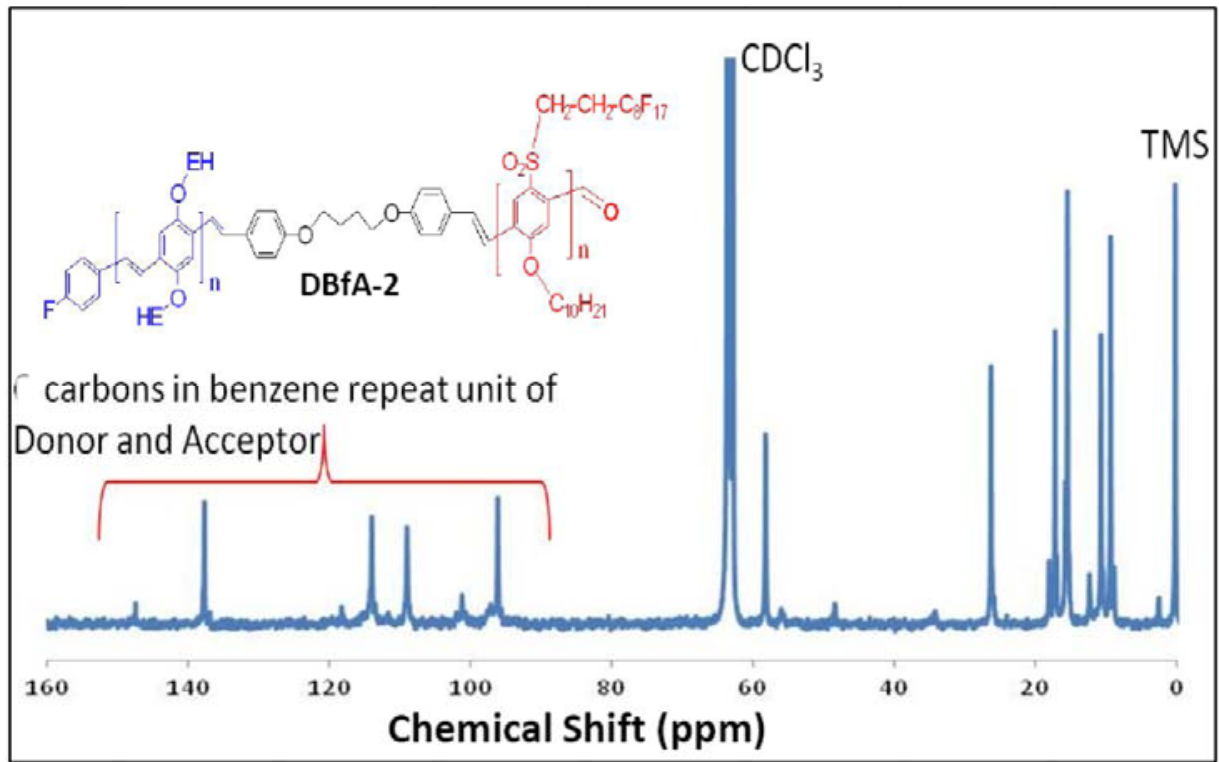

Figure 7: ${ }^{13} \mathrm{C}-\mathrm{NMR}$ spectrum of DBfA block copolymer.

(1) Deign and synthesis of an asymmetric functionalized and fluorinated acceptor monomer 9 (Scheme 1); (2) Design and synthesis of an mono-end functionalized conjugated donor block (D, Scheme 2). (3) Design and synthesis of amono-end functionalized donor bridge block (DB) and the coupling of (DB) with acceptor monomer $\mathbf{9}$ to form the final DBfA (Scheme 3). The molecular weight, degree of polymerization (DP), and polydispersity index (PDI) of the donor block D, a standalone acceptor block $f \mathbf{A}$, and the DBfA are listed in Table 1, and the polymerization reactions are controlled by mole ratio between two reactants which can be monomers or mono-end functionalized block copolymer and monomer [14].

The non-conjugated and flexible bridge $\mathbf{B}$ was prepared with four methylenes units $\left(\mathrm{CH}_{2}\right)$ instead of two as shown in Scheme 3 [13,14]. The fluorinated terminator was synthesized based on literature procedure $[19,20]$. The new asymmetric functionalized

Table 1: Molecular Weights, Degree of Polymerication (DP), and Polydispersity Index (PDI) of Synthesized Polymers Measured by GPC

\begin{tabular}{|c|c|c|c|c|c|}
\hline Polymers & $\begin{array}{c}\mathbf{M}_{\mathbf{w}} \\
(\mathbf{g} / \mathbf{m o l})\end{array}$ & $\begin{array}{c}\mathbf{M}_{\mathbf{n}} \\
(\mathbf{g} / \mathbf{m o l})\end{array}$ & $\begin{array}{c}\mathbf{M}_{\mathbf{p}} \\
(\mathbf{g} / \mathbf{m o l})\end{array}$ & PP \\
\hline \hline D & 15600 & 7200 & 11400 & 19 & 2.17 \\
\hline fA & 3600 & 3500 & 3500 & 5 & 1.03 \\
\hline DBfA & 17000 & 11300 & 9900 & 1.50 \\
\hline
\end{tabular}


and fluorinated acceptor monomer 9 was designed and prepared in eight synthetic steps from starting materials mercaptophenol $\mathbf{1}$ as shown in Scheme 1. In ${ }^{1} \mathrm{H}-\mathrm{NMR}$ spectra as shown in Figure 1, intermediate compound 2 was synthesized according to a literature procedure with a better yield $95 \%$ instead of $62 \%$ [18]. Compound 3 was obtained by Williamson etherification reaction from 2. Compound 4 was synthesized by carefully controlled mono-bromomethyation of compound 3 [13, 14]. Purification of $\mathbf{4}$ was not performed due to its limited stability in air. However, the crude product $\mathbf{4}$ was pure enough to give a neat ${ }^{1} \mathrm{H}-\mathrm{NMR}$ spectrum after a careful work-up, and compound 5 was obtained by the Arbuzov reactions from compound 4 [21, 22], with the $\mathrm{CH}_{2}-\mathrm{PO}(\mathrm{OEt})_{2}$ double peak on compound $\mathbf{5}$ shown at $3.20 \mathrm{ppm}$ (Figure 1). Compound 6 was synthesized by asimilar synthetic procedure as compound 4. Compound 7 was prepared from 6 , with the disappearance of $-\mathrm{CH}_{2} \mathrm{Br}$ singlepeak at $4.70 \mathrm{ppm}$ by a new $-\mathrm{CH}_{2} \mathrm{OH}$ single peak at $4.85 \mathrm{ppm}$. Finally, the fluorinated monomer 9 was obtained:(1) by oxidizing sulfur from compound 7 using hyrogen peroxy $\left(\mathrm{H}_{2} \mathrm{O}_{2}\right)$ reagent and treated by $\mathrm{KOH}$. The $-\mathrm{SCH}_{2}$ - triple peak at $3.05 \mathrm{ppm}$ was disappeared, and a new $-\mathrm{SO}_{2} \mathrm{CH}_{2}$ - triple peak can be seen at $3.45 \mathrm{ppm}$. (2) by oxidizing of alcohol $-\mathrm{CH}_{2} \mathrm{OH}$ group using pyridinum chlorochromate (PCC) from intermediate compound 8. The $-\mathrm{CH}_{2} \mathrm{OH}$ single peak at $4.85 \mathrm{ppm}$ was disappeared, and a new aldehyde $-\mathrm{CHO}$ single peak characteristic 9 can be seen at $10.71 \mathrm{ppm}$. Chemical structure and purity of $\mathbf{9}$ was further confirmed by ${ }^{13} \mathrm{C}-\mathrm{NMR}$ (Figure 3 ) and the element analysis data. The asymmetric and difunctionalized donor monomer $\mathbf{1 3}$ was prepared in four steps from hydroquinone as shown in Scheme 2. In ${ }^{1} \mathrm{H}$ NMR spectra as shown in Figure 4, compound $\mathbf{1 0}$ was prepared based on an earlier procedure [13, 14]. Compound $\mathbf{1 1}$ was prepared by a similar synthetic procedure as compound $\mathbf{4}$ shown in Scheme 1 except using a $30 \% \mathrm{HBr} / \mathrm{HOAc}$ and different temperature $\left(60^{\circ} \mathrm{C}\right)$. Compound 12 was prepared by a similar synthetic procedure as compound $\mathbf{5}$ shown in Scheme 1 except using different temperature $\left(140^{\circ} \mathrm{C}\right)$. The $\mathrm{CH}_{2} \mathrm{PO}(\mathrm{OEt})_{2}$ double peak on compound 12 (see Figure 4) can be seen at 3.30 ppm. Compound 12 was formulated by $\mathrm{Cl}_{2} \mathrm{CHOMe} / \mathrm{TiCl}_{4}$ to give the donor monomer 13, and a new aldehyde - $\mathrm{CHO}$ single peak of 13 can be seen at $10.45 \mathrm{ppm}$. Chemical structure and purity of $\mathbf{1 3}$ was further confirmed by ${ }^{13} \mathrm{C}-\mathrm{NMR}$ and the element analysis data [13, 14].

For comparison study purpose, a standalone acceptor fA block was synthesized by coupling a desired reactant ratio of monomer $\mathbf{9}$ with the fluorinated terminator which is catalyzed by sodium hydride $(\mathrm{NaH})$ in dry tetrahydrofuran. It appears $\mathrm{fA}$ is very sensitive to strong bases such as t-BuOK as compared to non fluorinated acceptor A conjugated blocks as reported earlier [14]. Although these conjugated acceptor blocks have the same sulfone $\left(-\mathrm{SO}_{2}\right)$ acceptor unit directly attached on backbone benzene, the new fA block also bear additional fluorinated side chains that are linked to the sulfone unit by a short $-\mathrm{CH}_{2} \mathrm{CH}_{2}$ - chain. The combination of the sulfone unit and the fluorinated alkyl groups on each acceptor unit makes the vinylene $\mathrm{CH}=\mathrm{CH}$ - bonds of $\mathbf{f A}$ block more electron-deficient and therefore much more susceptible to Michael addition side reactions [23]. Thus, the fA acceptor block was synthesized by coupling monomer 9 and F-terminator in a weaker base $\mathrm{NaH}$ instead. Upon synsthesis of $\mathbf{f A}$ block, the aldehyde peak at $10.7 \mathrm{ppm}$ from the monomer 9 was almost completely disappeared (tiny aldehyde peak could be due to unreactied acceptor monomer), and a vinylene peak $(-\mathrm{CH}=\mathrm{CH}-)$ between phenylene units and a double peak from F-terminator can be seen at $8.35 \mathrm{ppm}, 7.18 \mathrm{ppm}$ respectively. The fA block appears do not exhibit cis- double bond structural feature significantly as that of the $\mathbf{D}$ block. The new vinylene peak $(-\mathrm{CH}=\mathrm{CH}-)$ between phenylene units of $\mathbf{f A}$ can be seen at $8.35 \mathrm{ppm}$, and the functional phosphonate end group may be overlaped with the $\mathrm{CH}_{2} \mathrm{SO}_{2^{-}}$peak at $3.20-3.30 \mathrm{ppm}$. Due to this functional phosphonate end group wasn't shown clearly, the fA block was not used to synthesize the DBfA, instead, the DBfA was synthesized by coupling the DB with fluorinated monomer $\mathbf{9}$ directly as shown in Scheme 3, where the proton NMR spectra are shown in Figure 6.

The synthesis of DB, DBfA via Horner Wadsworth Emmons method is shown in Scheme 3, where the reactions were all carried out inside an inert gas chemical glove box at room temperature. Donor block D was obtained by a reaction between monomer 13 and the F-terminator in the presence of $\mathrm{t}-\mathrm{BuOK}$ in dry tetrahydrofuran. In D block, the vinylene peak ($\mathrm{CH}=\mathrm{CH}-$ ) between phenylene units can be seen at 6.85 $\mathrm{ppm}$, and the functionalized phosphonate end group can be seen at $3.20 \mathrm{ppm}$. The cis- double bond peak (single peak, $-\mathrm{OCH}_{2}$ ) can be seen at $3.47 \mathrm{ppm}$, and the trans- double bond peak (single peak, $-\mathrm{OCH}_{2}$ ) can be seen at $3.95 \mathrm{ppm}$. Donor-bridge DB was formed by coupling of large excess non-conjugated bridge $\mathbf{B}$ with D in the presence of t-BuOK in tetrahydrofuran. The functionalized phosphonate end group from $\mathbf{D}$ at 3.20 
ppm was completely disappeared, and the functionalized aldehyde end group of bridge unit can be seen at 9.90 ppm upon DB formation as shown in Figure 6. Two double peaks on benzene ring of the bridge once can be seen at 7.85 ppm and once was overlapped with the vinylene peak of $\mathbf{D}$ at $6.85 \mathrm{ppm}$. Finally, DBfA was synthesized from the coupling of DB with monomer $\mathbf{9}$ (in a mole ratio of $1: 21$ ) in the presence of $\mathrm{NaH}$ in dry tetrahydrofuran. In DBfA proton spectrum, key characteristic peaks from the $\mathbf{D}$ block remained, while the phosphonate $-\mathrm{CH}_{2}-\mathrm{PO}(\mathrm{OEt})_{2}$ double peak at 3.39 ppm from monomer 9 were completely consumed. Two new peaks, one at 3.30 ppm (corresponding to $-\mathrm{SO}_{2}-\mathrm{CH}_{2}-\mathrm{CH}_{2}-\mathrm{C}_{8} \mathrm{~F}_{17}$ ) and another at $2.50 \mathrm{ppm}$ (corresponding to $-\mathrm{SO}_{2}-\mathrm{CH}_{2}-\mathbf{C H}_{2}-$ $\mathrm{C}_{8} \mathrm{~F}_{17}$ ) from the acceptor block appeared. $A$ new functionalized aldehyde end group from fA block can be seen at 9.85 ppm. A vinylene peak between phenylene units of acceptor $\mathbf{f A}$ block can be seen at 7.85 ppm and 8.35 ppm respectively.

\subsection{Molecular Weight Characterizations}

The average molecular weights ( $\mathrm{Mn}, \mathrm{Mw}$, and $\mathrm{Mv}$ ), degree of polymerization (DP), and polydispersity index (PDI) of the synthesized polymers are listed in Table 1. Based on the GPC measurements, a dominant repeat units of 19 based on the measured number average molecular weight $(\mathrm{Mn})$ of $\mathbf{D}$ is quite close to a value of 20 based on the calculated or expected Mn according to a monomer: terminator mole ratio of $20: 1$. A measured dominant repeat unit of 4 based on measured $\mathrm{Mn}$ of $\mathbf{f A}$ is much smaller than an expected value of 20 based on monomer: terminator mole ratio of 20:1. The cause of such shorter than expected $\mathbf{f A}$ size is possibly due to a significantly decreased chemical reactivity of $\mathbf{f A}$ block after 4 repeating units of fA were formed. The measured average molecular weights of DBfA also confirmed such shorter fA acceptor block size. MALDI-TOF studies also confirmed that fA block exhibited up to five repeat units chain size (Figure $\mathbf{8}$ ) as compared to the $\mathbf{D}$ block that exhibits up to 25 repeating units (Figure 9). Note the MALDI-TOP molecular weight distribution does not reflect well the actual molecular weight distribution as that of GPC due to fragmentations or break down of large molecules in MALDI-TOP measurements. Also, DBfA did not exhibit clear or reliable MALDI-TOF results possibly due to the complexity of DBfA molecular structure fragmentations and particularly the high molecular weights of DBfA that are well over the MALDI-TOF detection limit (10000 Daltons in this case).

\subsection{Thermal Property Characterizations}

DSC and TGA were measured to study the thermal properties of the synthesized polymers. TGA curves of these polymers are shown in Figure 10, and the 5\% weight loss onset temperatures are listed on Table 2. The cause of much lower mass loss start $\left(\right.$ at $\left.300^{\circ} \mathrm{C}\right)$ of fA as compared to $\mathbf{D}\left(\right.$ at $380^{\circ} \mathrm{C}$ ) and DBfA (at $350^{\circ} \mathrm{C}$ ) is

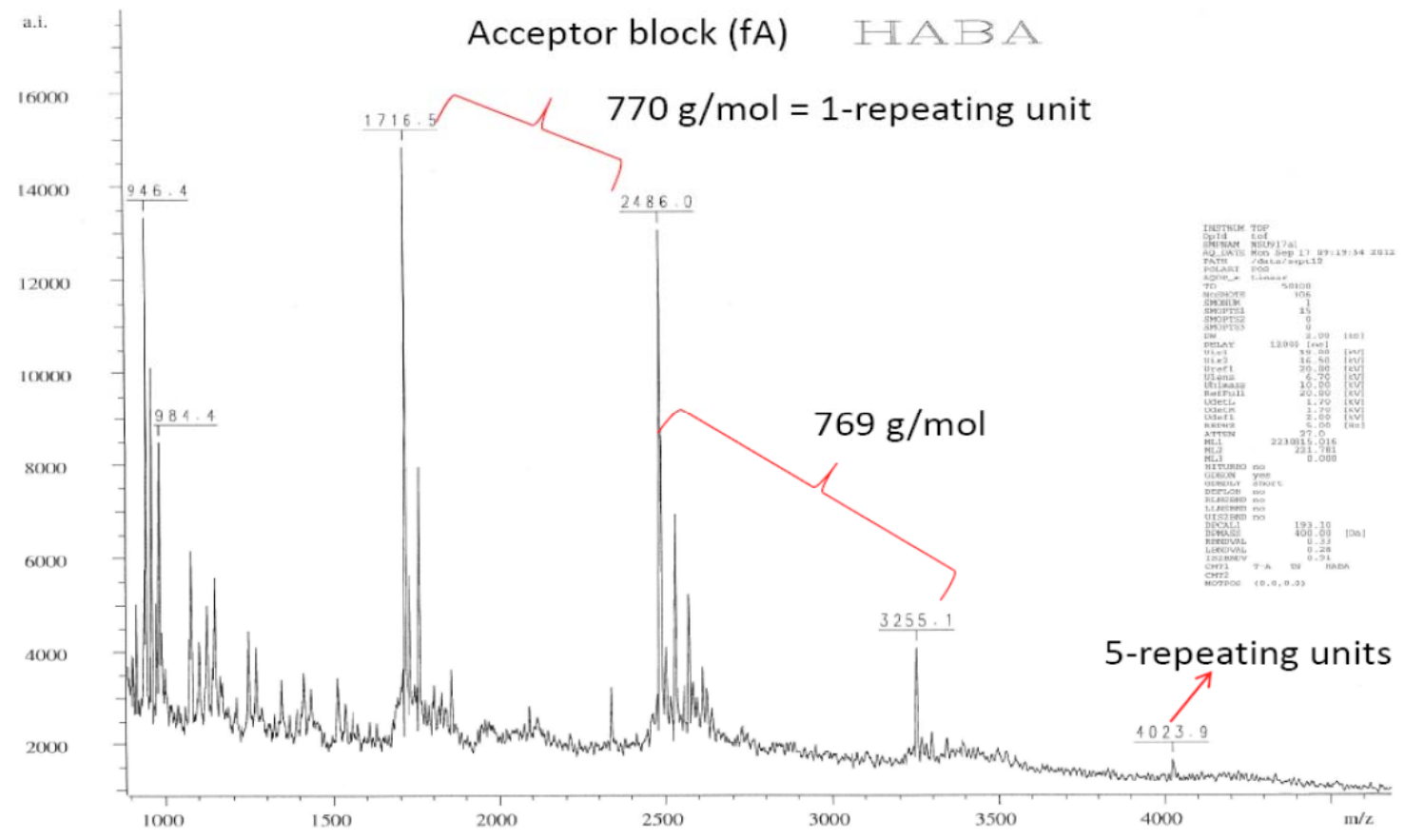

Figure 8: MALDI-TOF spectrum of $\mathbf{f A}$ acceptor block. 


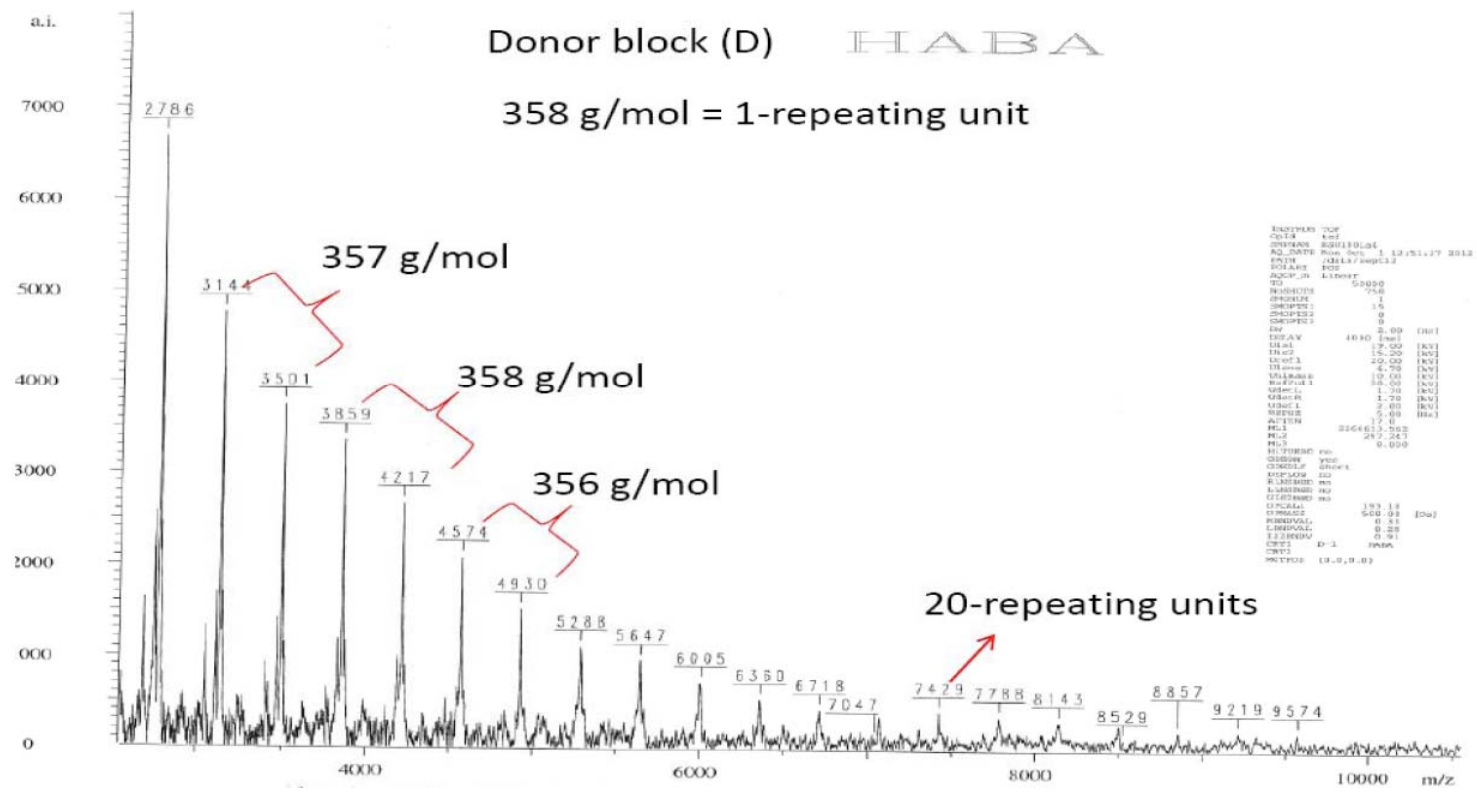

Figure 9: MALDI-TOF spectrum of $\mathbf{D}$ block.

Table 2: Thermal Properties of Synthesized Polymers

\begin{tabular}{|c|c|c|}
\hline Polymers & DSC Endothermic Peaks Onset T $\left({ }^{\circ} \mathbf{C}\right)$ & TGA 5\% Drop Onset T $\left({ }^{\circ} \mathbf{C}\right)$ \\
\hline \hline D & $93-245$ & 380 \\
\hline fA & 78 & 300 \\
\hline DBfA & $72-230$ & 350 \\
\hline
\end{tabular}

possibly due to the much smaller molecular size and/orless chemical stability of fA. DSC scans of these polymers are shown in Figure 11. In the low temperature regine $\left(\mathrm{RT}-200{ }^{\circ} \mathrm{C}\right), \mathbf{D}, \mathbf{f A}$, and DBfA undergo an exothermic transitions at $93,78,72{ }^{\circ} \mathrm{C}$, respectively. $D$ and $\mathbf{f A}$ exhibit second exothermic transitions at 245 and $230{ }^{\circ} \mathrm{C}$, respectively. The onset decomposition temperatures of all copolymers are over $320^{\circ} \mathrm{C}$.

\subsection{Electrochemical and Optoelectronic Properties}

Optical UV-Visabsorption spectra were measured to obtain absorption maximum peak wavelength $\left(\lambda_{\max }\right)$ and the onset optical energy gap $\left(E_{g}{ }^{\text {opt }}\right)$ of these polymers in THF solutions. $E_{g}{ }^{\text {opt }}$ is calculated from the formula $E_{\text {gap }}^{o p t}=1240 / \lambda_{\text {cutoff }}$ where $\lambda_{\text {cutoff }}$ is the absorption peak low energy onset wavelength. The UV-Vis spectra of D, fA and DBfA are shown in Figure 12.

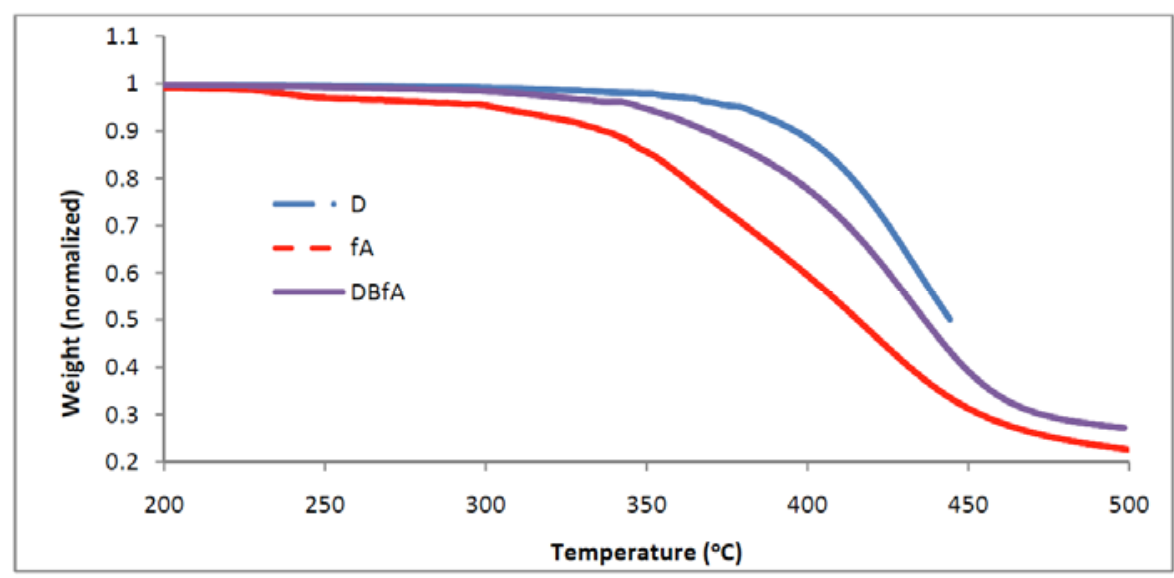

Figure 10: TGA curves of synthesized copolymers. 


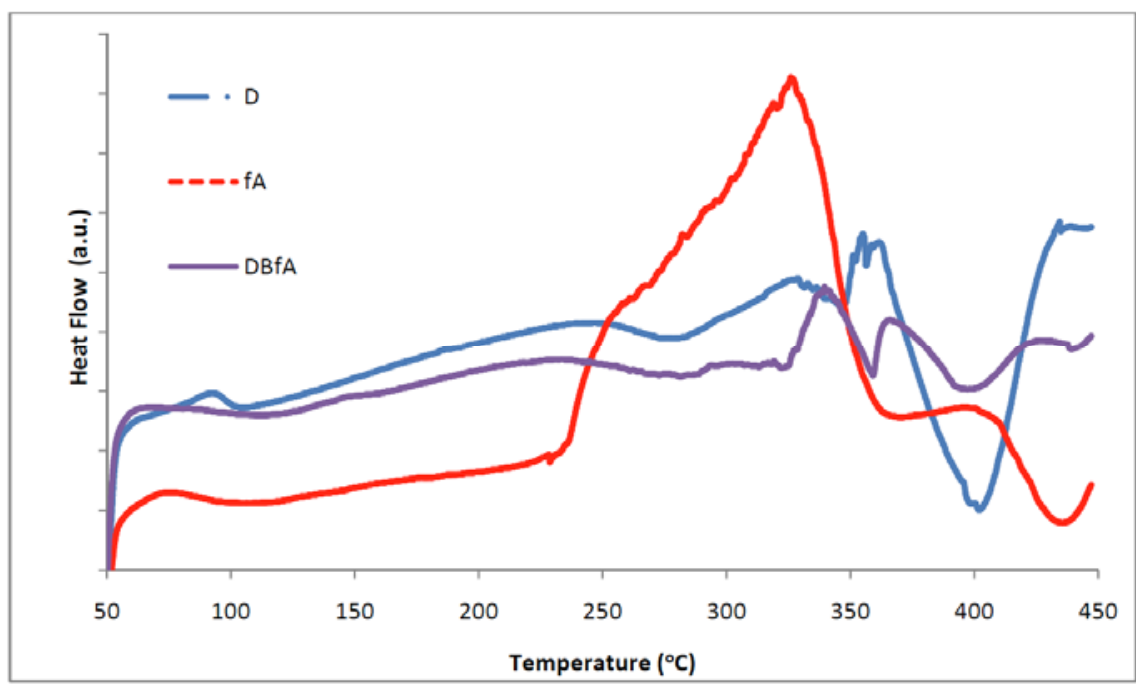

Figure 11: DSC curve of synthesized polymers.

Table 3: Optical and Electrical Properties of D and fA

\begin{tabular}{|c|c|c|c|c|c|}
\hline Polymers & $\begin{array}{c}\lambda_{\max } \\
(\mathbf{n m} \text { in THF) }\end{array}$ & $\begin{array}{c}\lambda_{\text {onset }} \\
(\mathbf{n m} \text { in THF) }\end{array}$ & $\begin{array}{c}\text { Optical } \\
\mathbf{E}_{\mathbf{g}}(\mathrm{eV})\end{array}$ & $\begin{array}{c}\text { Onsetsin Cyclic } \\
\text { Voltammetry } \\
(\text { Volt })\end{array}$ & $\begin{array}{c}\text { HOMO/LUMO Levels (Based on } \\
\text { Ferrocene HOMO of -4.8eV) } \\
(\mathbf{e V})\end{array}$ \\
\hline \hline D & 495 & 574 & 2.16 & Oxidation: 0.70 & $-5.22 /-3.06$ \\
\hline fA & 370 & 464 & 2.67 & Reduction: -1.0 & $-6.10 /-3.43$ \\
\hline
\end{tabular}

Electrochemical cyclic voltammetry (CV) curves of D and $\mathbf{f A}$ are shown in Figure 13. Optical absorption peak and onset wavelengths, emission peak wavelength, and the frontier orbital data of $\mathbf{D}$ and $\mathbf{f A}$ are listed in Table 3. As shown in Figure 12, the UV-Vis absorption of DBfA exhibited two absorption maximum region, where the absorption at $340 \mathrm{~nm}$ corresponds to the D block and the absorption at $494 \mathrm{~nm}$ corresponds to $\mathrm{fA}$ block. A simple overlap of individual block optical absorption imply there is no ground state charge seapartion in DBfA which is desirable in photoelectric (or excited state charge separation) applications. The much wider energy gap of $\mathbf{f} \mathbf{A}$ as compared to $\mathbf{D}$ block can be explained by the much shorter conjugation length of fA (3 5 repeat units) as compared to D(19 20 repeat units) based on a "particle-in-a-box" quantum principle [24], as well as a fA repeat unit intra repeat unit electron-transfer between donor alkyloxy and acceptor sulfone across the benzene ring, this would result in a quinoidal resonance structure formation interfering the charge coupling and delocalization on the main chain $[25,26]$. The frontier orbital levels of HOMO/LUMOs are estimated from UVVis absorption (Figure 12, where the energy gap $E_{g}$ is obtained) in combination with electrochemical cyclic voltammetry measurements (Figure 13, where either HOMO or LUMO values are obtained). The HOMO levelof the sample is calculated from the formula $E_{(\text {Sample, }}$ номо) $=E_{(\text {Ferrocene, }}$ номо $)+E_{(\text {Ferrocene, pos-ox })^{-}}$
$E_{(\text {Sample, pos-ox) }}$, and the LUMO level is calculated from the formula $E_{(\text {Sample, LUMO })}=E_{(\text {Ferrocene, HOMO })}+E_{(\text {Ferrocene, }}$ pos-red) $)^{-} E_{(\text {Sample, neg-red), where }} E_{(\text {Ferrocene, pos-ox })}$ is the upward oxidation onset of the Ferrocene HOMO peak at positive potential scan, and $E_{(\text {Ferrocene, pos-red) }}$ is the downward reduction onset of the Ferrocene $\mathrm{HOMO}$ peak at positive potential scan, and $\mathrm{E}_{(\text {Ferrocene, HOMO)= - }}$ $4.80 \mathrm{eV}$ [24]. Table 3 lists the HOMO oxidation onsets of both $\mathbf{D}$ and $\mathbf{f A}$, so their HOMO levels are calculated. The other frontier orbital (LUMO) are than estimated from the UV-V is absorption band edge that approximates the HOMO-LUMO gap or $\mathrm{E}_{g}$.

Photoluminescence spectra of $\mathbf{D}, \mathbf{f A}$ and DBfA in THF solution are shown in Figure 14. Different excitations (372, 490, $492 \mathrm{~nm})$ were used to excite fA, D, and DBfA respectively. The PL emission peak wavelength of $\mathrm{fA}$ is at $460 \mathrm{~nm}$. The $\mathrm{PL}$ peak/shoulder peak wavelengths of $\mathbf{D}$ is at 556 . The $\mathrm{PL}$ emission peak wavelengths of DBfA are at 456 and $550 \mathrm{~nm}$ indicating the presence of both $\mathbf{f A}$ and $\mathbf{D}$ segments. PL spectra of $\mathbf{D}$ and DBfA (same donor repeat unit concentration at $3.0 \times 10^{-7} \mathrm{M}$, and excited at donor excitation wavelength of $490 \mathrm{~nm}$ ) in THF solutions are shown in Figure 15. In this measurement, $\mathbf{D}$ exhibited a more than $60 \%$ photoluminescence $(\mathrm{PL})$ quenching in DBfA compared to pristine $\mathbf{D}$. The PL quenching could 


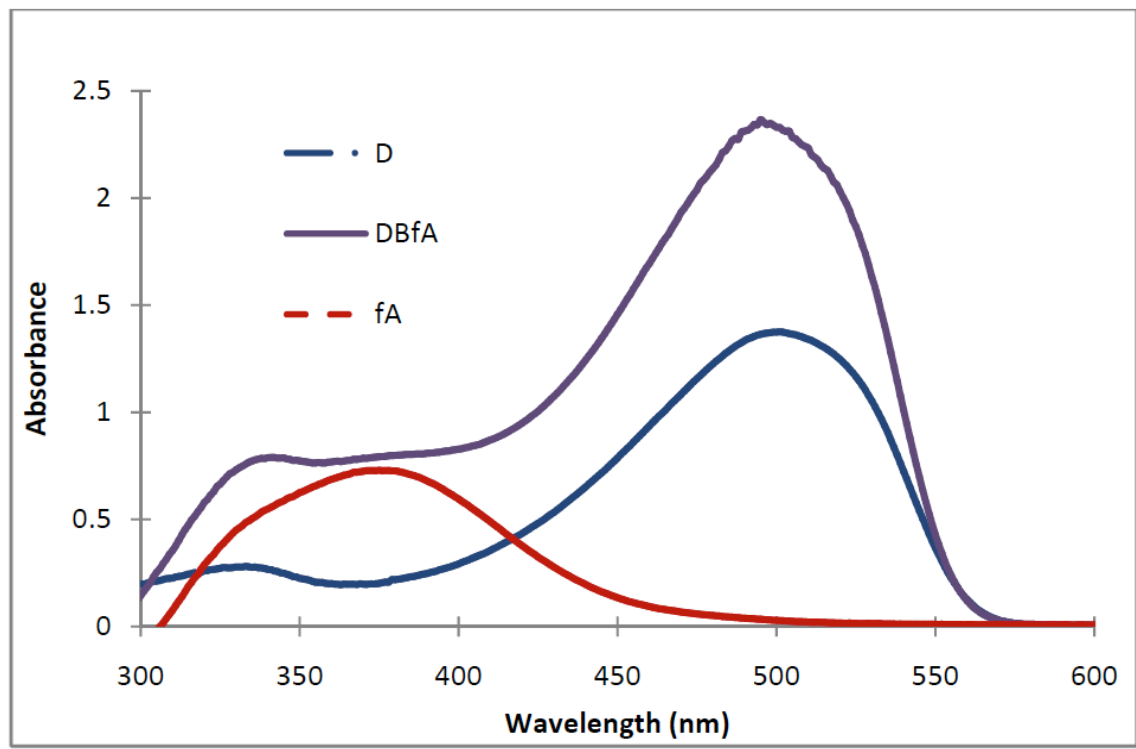

Figure 12: UV-Vis spectra of synthesized polymers in THF.

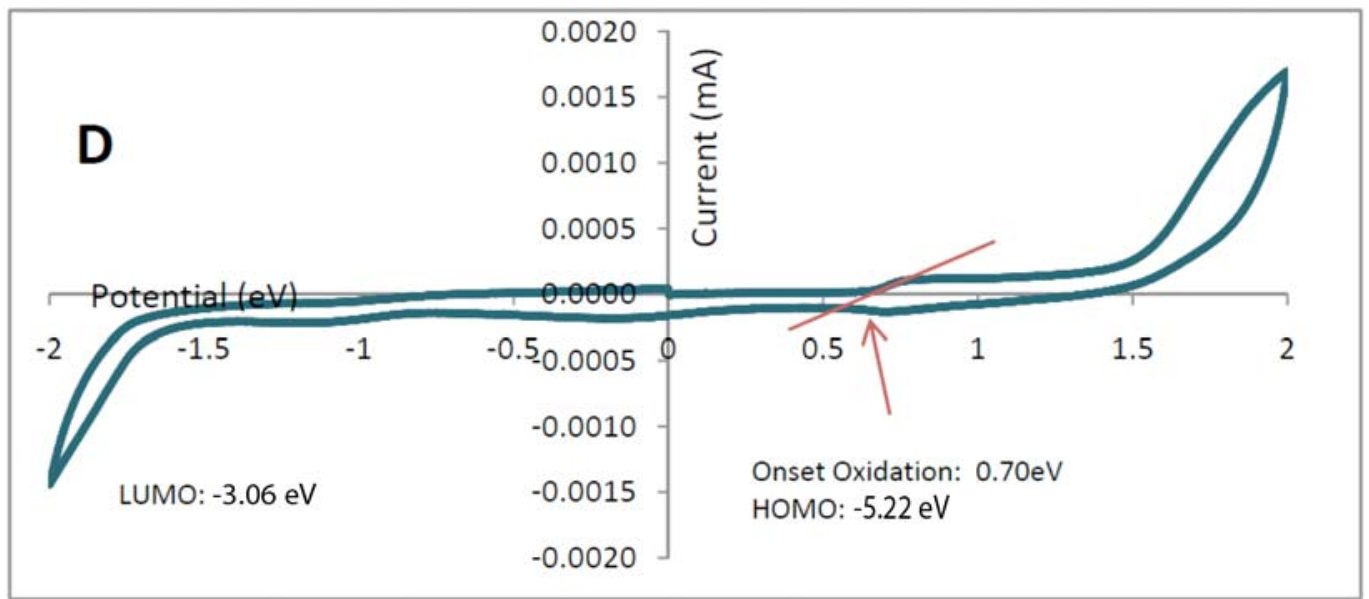

(a)

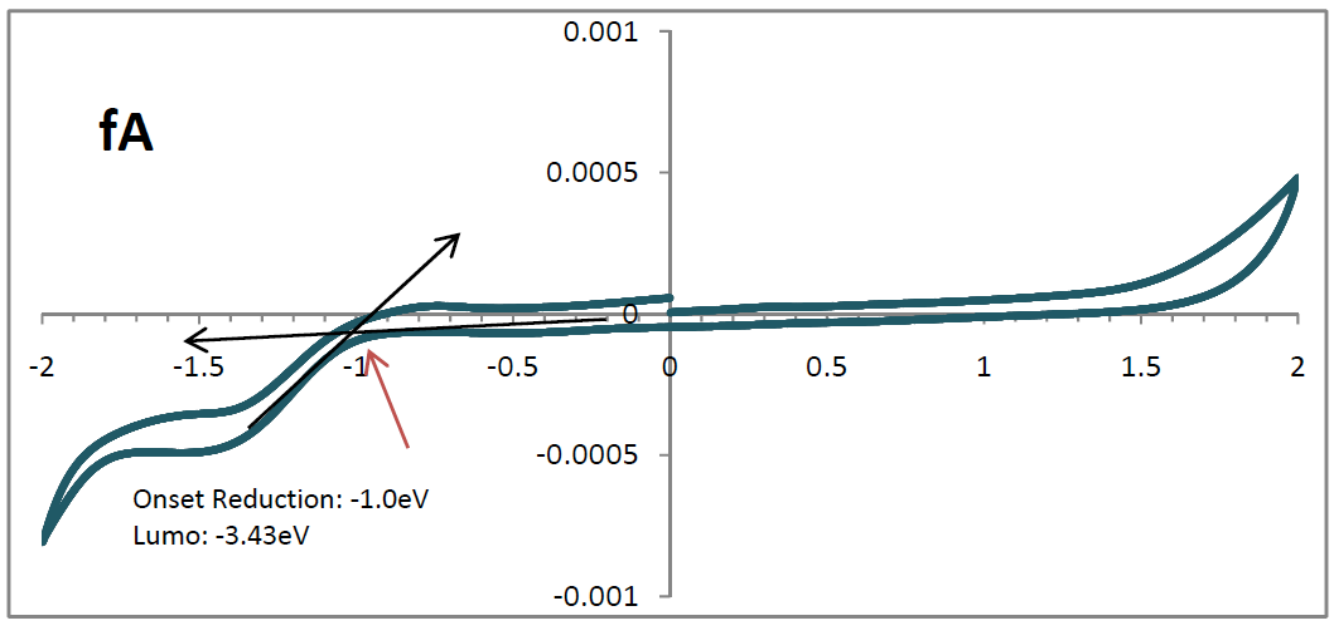

(b)

Figure 13: Cyclic voltamograms (CV) of (a) D and (b) fA films coated on Pt wire. Reference electrode: $\mathrm{Ag}$ wire in $0.1 \mathrm{M}$ $\mathrm{AgNO}_{3} / \mathrm{MeCN}$. 


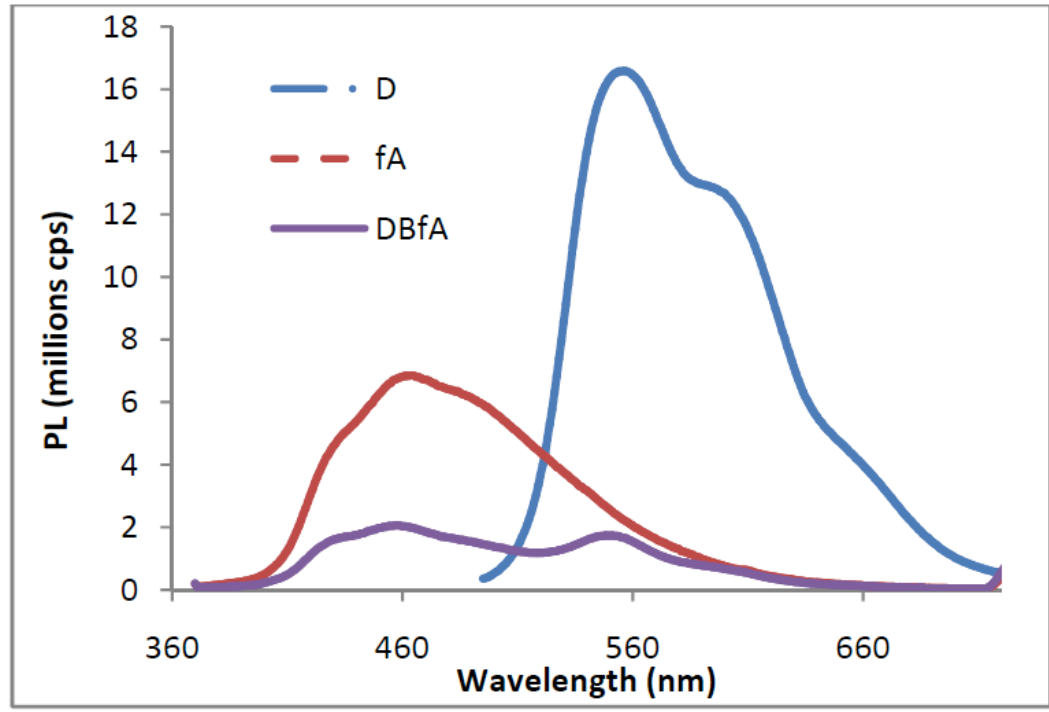

Figure 14: Photoluminescence spectra of synthesized polymers in THF.

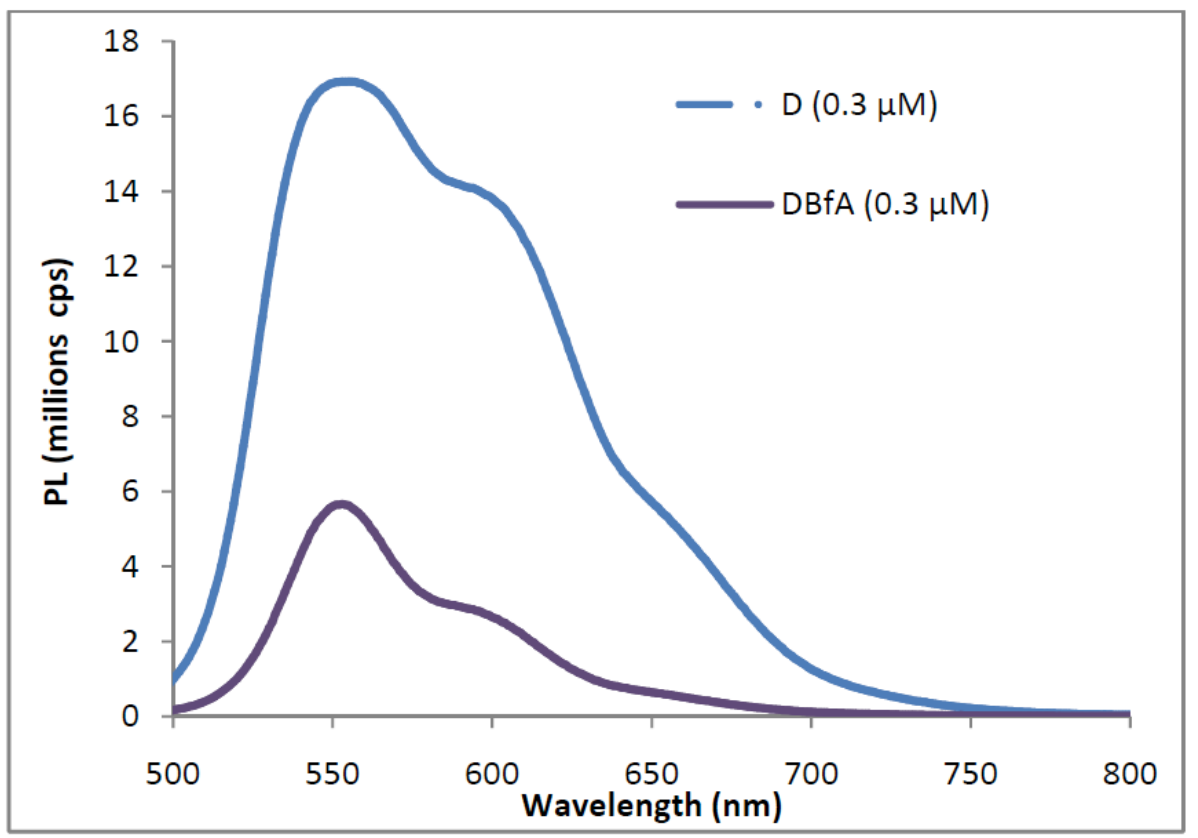

Figure 15: Photoluminescence spectra of $\mathbf{D}$ and $\mathbf{D B f A}$ in THF with same concentration of $\mathbf{D}$ repeating units.

be attributed to the photo induced electron transfer from $D$ block to fA block in DBfA.

\subsection{Thin Film Processing and Morphological Studies}

All polymer thin film samples are prepared by spin coating polymer solutions (typically $10.0 \mathrm{mg}$ polymer dissolved in $1.0 \mathrm{ml}$ o-dichlorobenzene) to a thickness of $1 \sim 2$ micron on regular glass substrates. For $150^{\circ} \mathrm{C}$ thermally annealed and dried films, the topography and phase images of atomic force microscopy (AFM) at half micron scales of D/fA blend films and DBfA films are shown in Figure 16. As the images in Figure 16 (b) and (d) shows, DBfA films exhibit phase domain sizes similar to the polymer block sizes, but the D/fA blend films in images (a) and (c) did not yield any ordered domain sizes corresponding to the block sizes.

Thin film X-ray diffraction (XRD) data of drop casted D/fA blend and DBfA block copolymer films are shown Figure 17. Wide angle out-of-plane diffractograms were recorded via a Rigaku X-ray diffractometer Model D/max-220 (Cu Ka radiation, $\lambda=1.5406 \AA$ ) for these polymers on glass substrates. XRD's parameters are: general power $(40 \mathrm{kV}, 40 \mathrm{~mA})$, start/stop angle $(2 \theta=$ $2.0 / 40)$, step size $(0.05)$, scan speed (1.50), step time (1.50), scan time (38 mins). 

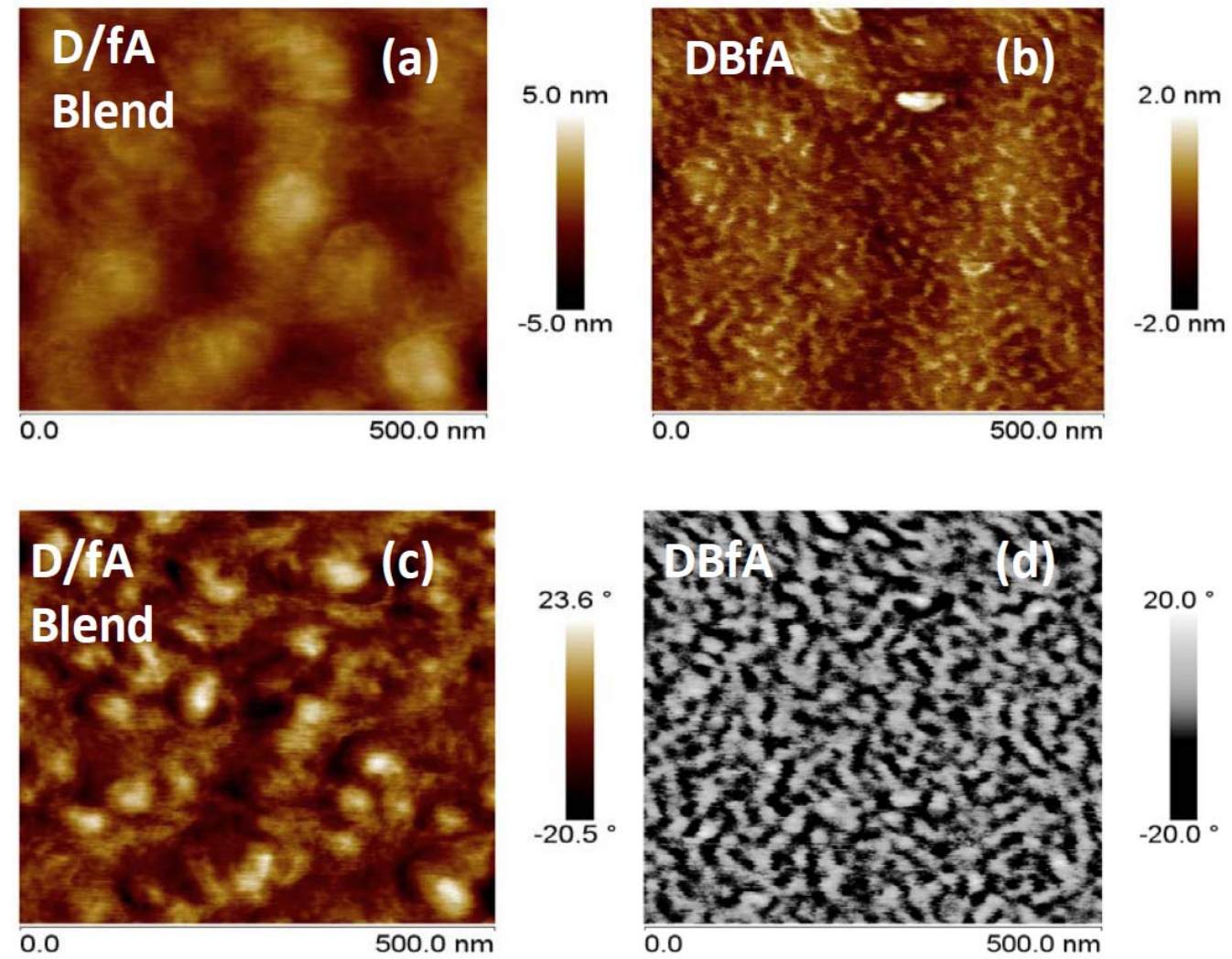

Figure 16: Atomic force microscopy (AFM) thin film topography images of (a) D/fA blend and (b) DBfA block copolymer, as well as thin film phase images of (c) D/fA blend and (d) DBfA block copolymer. All thin films were thermally annealed at $150^{\circ} \mathrm{C}$ for two hours.

As shown in Figure 17a, XRD of D/fA blend films didn't exhibit any crystalline peaks at room temperature and one hour thermal annealing at $150^{\circ} \mathrm{C}$, however, a crystalline peak appeared after thermally annealed at $150^{\circ} \mathrm{C}$ for two hours. In contrast, as shown in Figure 17b, XRD of DBfA exhibited a weak crystalline peak at room temperature and strong crystalline peaks after thermally annealed at $150^{\circ} \mathrm{C}$ for one and two hours. As shown in Figure 17c, bare glass substrated did not exhibit any diffraction peaks, while the D/fA blend film and the DBfA film thermally annealed at $150^{\circ} \mathrm{C}$ for two hours exhibited crystalline diffraction peaks with a strong first order diffraction peaks and a good second diffraction peaks. The diffraction angle $(2 \theta)$ of $8.95^{\circ}$ for the first diffraction peak (100) corresponds to a crystalline d-spacing of $9.88 \AA$. The diffraction angle

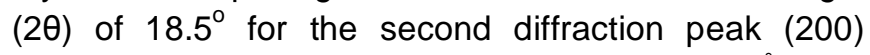
corresponds to a crystalline d-spacing of $4.79 \AA$. The narrow first order diffraction peaks indicated that both D/fA blend and DBfA formed certain crystalline domains in thin film solid state upon thermal annealing at $150^{\circ} \mathrm{C}$ for two hours, but DBfA phase size and pattern appear significantly different from the D/fA blend, implying a possible self assembled morphology unique of DBfA block copolymer.

\subsection{Solar Cell Device Fabrications and Studies}

\section{Solar Cell Device Fabrications}

Active polymer solutions were prepared by dissolve a mixture of $15 \mathrm{mg}$ photovoltaic polymer samples (e.g. $15 \mathrm{mg}$ of DBfA for DBfA cells, or $7.5 \mathrm{mg} \mathbf{D}$ with $7.5 \mathrm{mg}$ fA for D/fA blend cells) mixed with $15 \mathrm{mg}$ acceptor $\mathrm{PC}_{71} \mathrm{BM}$ (so total active layer materials is $30 \mathrm{mg}$ ) dissolved in one milliliter o-Dichlorobenzene (DCB).

Solar cell devices were fabricated in five steps: (1) ITO glass substrates $(37.5 \mathrm{~mm} \times 25 \mathrm{~mm} \times 0.4 \mathrm{~mm}$ ITO slide, $R_{s}=8-12 \Omega$ ) were taped in the middle part (yellow and blue parts in Figure 18) with scotch tape to protect ITO from $\mathrm{HCl}$ dissolution, then the taped slides were immerged in $6 \mathrm{M} \mathrm{HCl}$ for 15 minutes to etch away ITO outside the tape area (grey part in Figure 18). (2) After $\mathrm{HCl}$ etching, ITO slides were rinsed with DI water and the scotch tape were removed immediately. Then the ITO slides were sonicated for five minutes each in soap/DI water, DI water, acetone, and 2-propanol, respectively, then blown dried with compressed nitrogen. (3) Spin coat PEDOT:PSS aqueous solution (from H.C. Starck, filtered via a 0.45 micron filter) onto ITO side. The thin film spinning protocol typically 


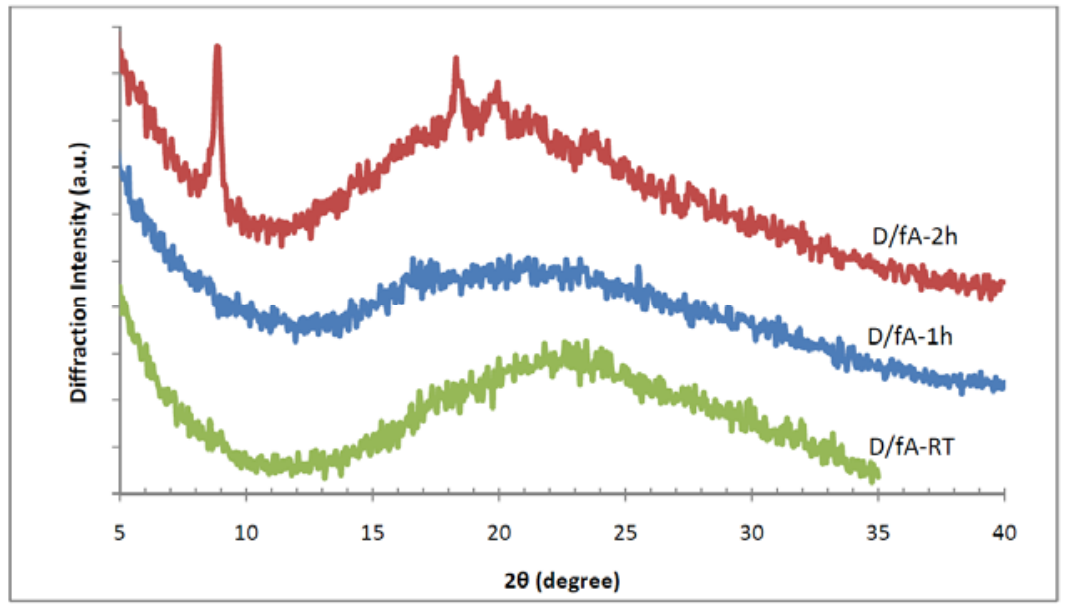

(a)

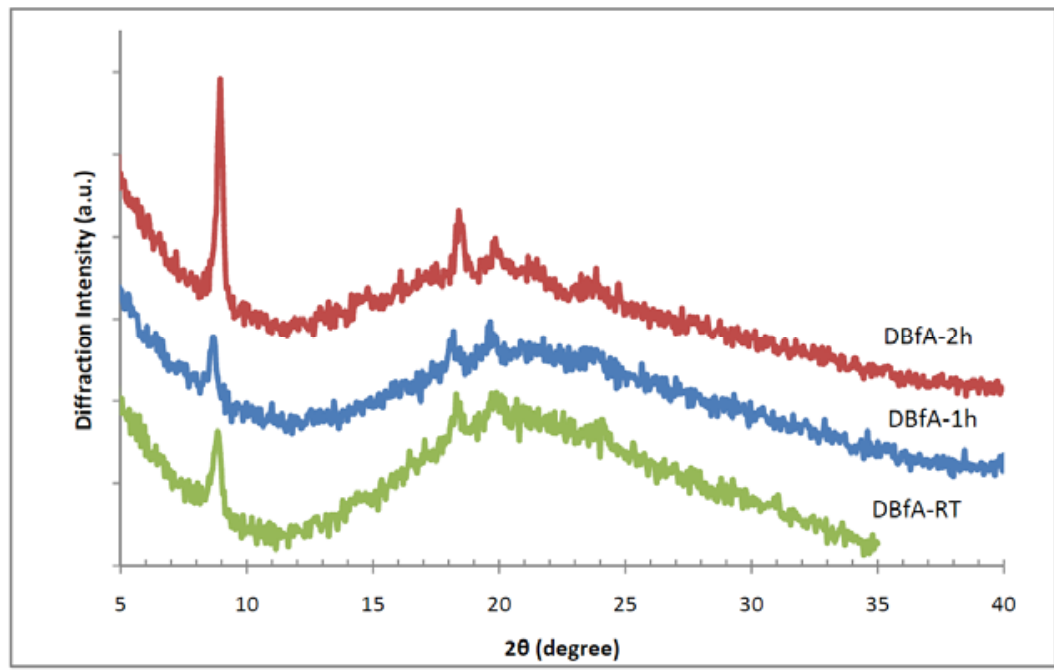

(b)

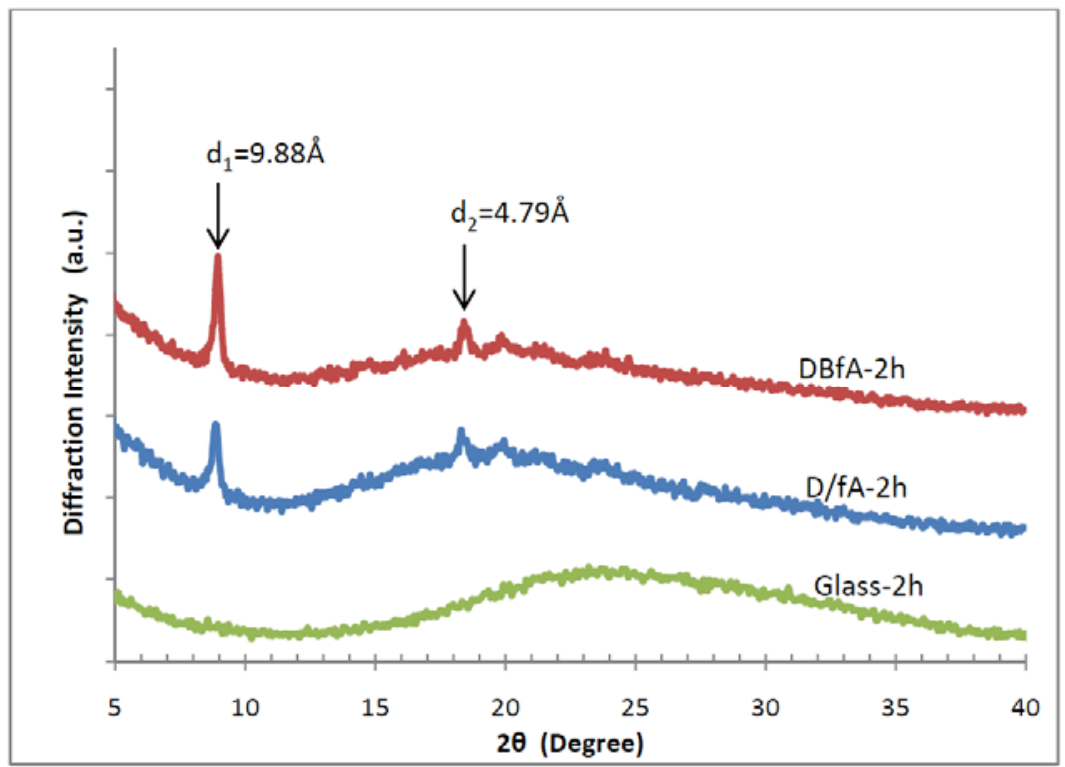

(c)

Figure 17: Thin film X-ray diffraction (XRD) of (a) D/fA blend film at room temp, $150^{\circ} \mathrm{C}$ annealed for $1 \mathrm{hr}$, and $150^{\circ} \mathrm{C}$ for $2 \mathrm{hrs}$; (b) DBfA film at room temp, $150^{\circ} \mathrm{C}$ for $1 \mathrm{hr}$, and $150^{\circ} \mathrm{C}$ for $2 \mathrm{hrs}$; and (c) D/fA and DBfA films annealed at $150^{\circ} \mathrm{C}$ for 2 -hours. (Bragg's law, $\mathrm{n} \lambda=2 \mathrm{~d} \sin \theta)$. Film's thickness: $1.5 \mu \mathrm{m}$ 


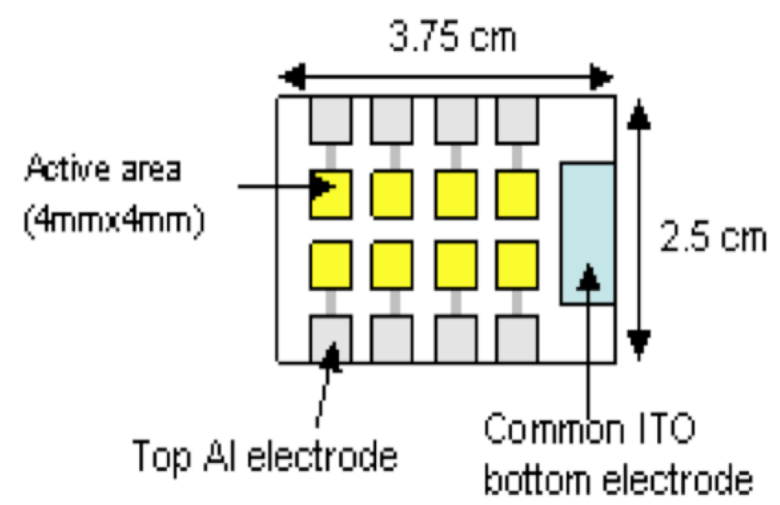

Figure 18: Scheme of eight solar cells fabricated on a ITO slide.

included a key step of 5000RPM for 30 seconds, yielding a $30-50 \mathrm{~nm}$ thick PEDOT:PSS film after dried at $120^{\circ} \mathrm{C}$ hot plate surface for half hour. (4) Spin coating the photovoltaic active polymer solution (via a 0.2 micron filter) on top of dried "ITO/PEDOT:PSS" film via a critical spinning step of 1000RPM for 60 seconds and subsequently drived in a $60-80^{\circ} \mathrm{C}$ heated vacuum oven for at least one hour, typically yielding a film thickness of 100-200 nm. (5) In an inert gas filled glove box, the polymer coated ITO slides were placed in a vacuum deposition jar, and the patterned metal (such as aluminum) electrodes (see Figure 18) were deposited to a thickness of about $100-150 \mathrm{~nm}$ on top of the active polymer layer by thermal evaporation under high vacuum $\left(1 \times 10^{-6}\right.$ to $1 \times 10^{-7}$ Torr $)$. After metal electrode deposition, the positive ITO electrode was exposed by scratching off a $3 \mathrm{~mm}$ diameter spot of polymer coating on the blue part of ITO (Figure 18). The negative electrode will be clipped to one of the eight cell aluminum electrode on the ITO edge.

\section{Device Studies}

An AM 1.5G solar simulator with one Sun or 100 $\mathrm{mW} / \mathrm{cm}^{2}$ intensity was used to study the efficiency of solar cell devices. A Keithley 237 source-measure unit (SMU) was used to collect the voltage-current data that were processed by computer into $\mathrm{J}-\mathrm{V}$ curves.

Solar cell devices were all composed of multiple stack of layers in a general sequence of ITO/PEDOT:
PSS/Polymer:PC ${ }_{70} \mathrm{BM} / \mathrm{Al}$. Cells made from $\mathbf{D} / \mathbf{f A}$ and DBfA as donor polymers were fabricated into solar cell devices and compared. Figure 19 exhibits the frontier orbital levels and/or work functions of all component materials of the cell. The open-circuit voltage $\left(V_{o c}\right)$, short-circuit current density $\left(J_{s c}\right)$, fill factor $(F F)$, and power conversion efficiencies $(\eta)$ of fabricated cells are listed in Table 4. A best photo $\mathrm{J}-\mathrm{V}$ curve (in log scale) among a set of eight cells made of either $\mathbf{D} / \mathbf{f A}$ blend or DBfA are shown in Figure 20, where the D/fA blend cell exhibits a best photoelectric power efficiency of about $0.002 \%$, while a DBfA cell exhibits a best photoelectric power conversion efficiency of about $0.2 \%$ i.e. a two orders of magnitude efficiency improvement was achieved in a DBfA cell as compared to a best $\mathbf{D} / \mathbf{f A}$ blend cell. The absolute efficiencies of the cells reported are still relatively low compared to other literature reported best organic cell values (between 5-10\%) due to, for instance, the PPVs reported here have much higher energy gaps (more than $2.2 \mathrm{eV}$ ) compared to popular donor type polymers (such as regio-regular P3HT) that exhibits lower energy gaps (less than $2.0 \mathrm{eV}$ ) and better charge transport, and our cell fabrication protocols as well as polymer solid state morphologies have not yet been systematically optimized. However, higher energy gaps and fluorination of the conjugated polymer may find important applications in certain higher energy radiations, or in applications where hydrophobicity or vacuum lubrication are desired [27]. The most

Table 4: Solar Cell Performance of ITO/PEDOT:PSS/Polymer:PC70BM/AI Bulk Hetero-Junction Photovoltaic Devices under AM $1.5 \mathrm{G} / 100 \mathrm{~mW} / \mathrm{cm}^{2}$. $V_{o c}=$ Open-Circuit Voltage, $J_{s c}=$ Short-Circuit Current, $F F=$ Fill Factor, and $P C E=$ Power Conversion Efficiency

\begin{tabular}{|c|c|c|c|c|}
\hline Polymers Used in the Cell & $J_{s c}\left(\mathbf{m A} / \mathbf{c m}^{2}\right)$ & $V_{o c}($ Volt $)$ & $F F(\%)$ & $P C E(\%$, Un-Calibrated) \\
\hline \hline D/fA blend & 0.052 & 0.20 & 19 & 0.0020 \\
\hline DBfA & 1.21 & 0.65 & 28 & 0.22 \\
\hline
\end{tabular}




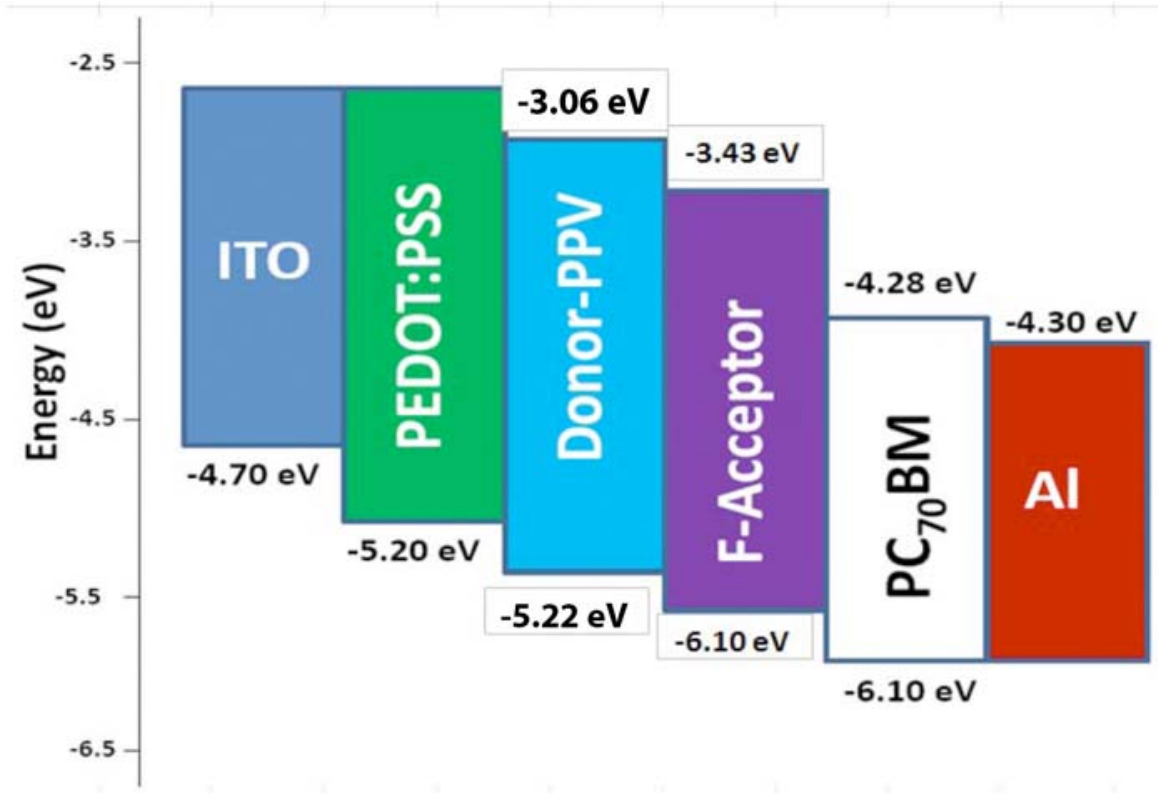

Figure 19: Frontier orbital energy levels of materials used in fabricating solar cells.

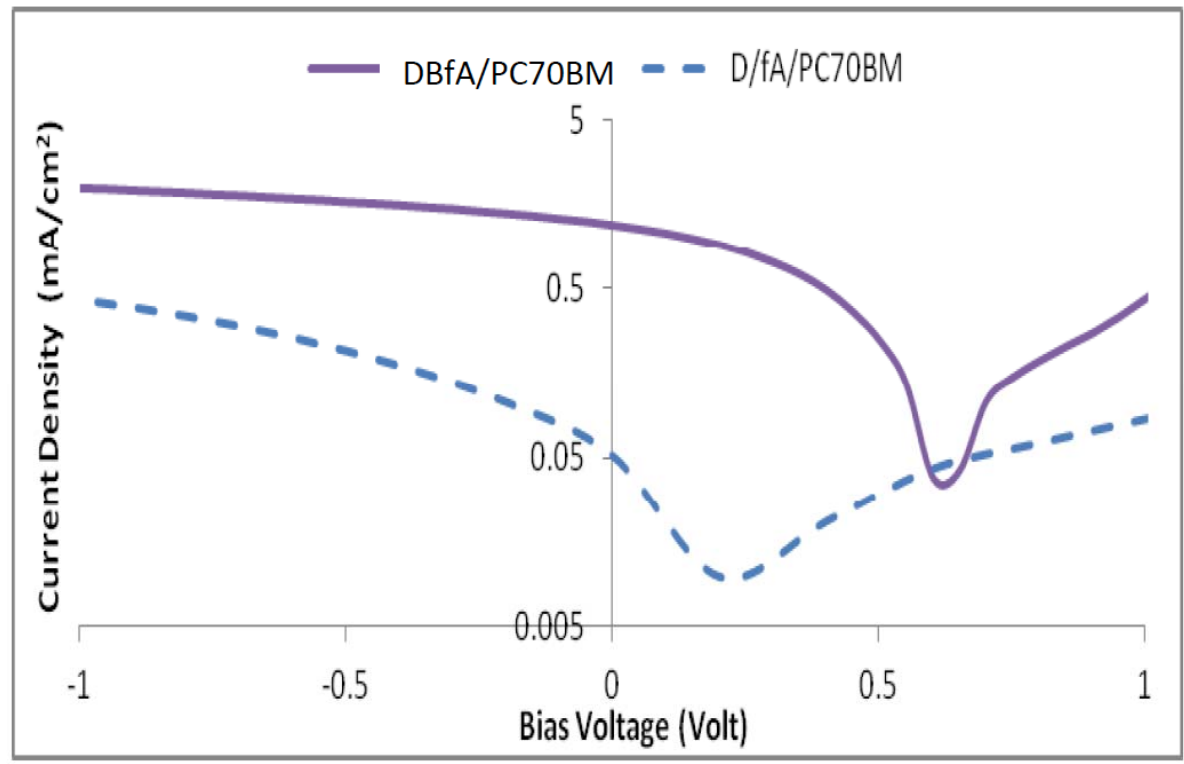

Figure 20: Photo J-V curves (in log scale, under $\mathrm{AM} 1.5 \mathrm{G}$ one Sun intensity) ofa best solar cell made from the $\mathrm{DBfA}_{\mathrm{P}} \mathrm{PC}_{70} \mathrm{BM}$ (solid line) and a best solar cell made from the blend of $\mathrm{D} / \mathrm{fA} / \mathrm{PC}_{70} \mathrm{BM}$ (dashed line). The power conversion efficiency of the DBfA/PC 70 BM cellis $0.22 \%$, over two orders of magnitude larger than the $\mathbf{D} / \mathbf{f A} / \mathrm{PC}_{70} \mathrm{BM}$ cell (efficiency $0.0020 \%$ ).

important finding of this study is that DBfA block copolymer exhibited two orders of magnitude better photoelectric power conversion efficiency than the simple D/fA blend under identical or similar conditions. Due to the identical frontier orbital levels of $D$ and $f A$ in D/fA blend cells and in the DBfA cell, we therefore attribute such significant improvement of photo electric conversion efficiency mainly to the spatial regime or morphological improvement in the DBfA block copolymer cells as compared to the D/fA blend cells. Specifically, in DBfA cell, more photo generated excitons are able to reach the donor/acceptor interfaces and dissociate into charged carriers due to both donor and acceptor domains sizes in DBfA are less than the average exiton diffusion length. The charge transport in DBfA could also be better than in D/fA blend due to more ordered and bicontinuous nano morphology as shown in Figure 16.

\section{SUMMARY AND CONCLUSION}

In summary, a novel DBfA type block copolymer system composed of an acceptor type and fluorinated 
conjugated PPV block $\mathrm{A}$ A covalently linked to a donor type conjugated PPV block D via a non-conjugated bridge unit $\mathbf{B}$ has been designed, synthesized, characterized, and preliminarily evaluated for optoelectronic applications. Specifically, the HOMO/LUMO levels for $\mathbf{D}$ and $\mathbf{f A}$ blocks are $-5.22 /-3.06$ and $-6.10 /-3.43$ respectively which fits nicely between the energy levels of the hole collecting PSS:PEDOT and the electron collecting $\mathrm{PC}_{70} \mathrm{BM}$. Solid state thin film studies revealed more uniform and nanoscale phase separated morphologies in DBfA as compared to D/fA blend. Preliminary solar cell device studies revealed that, a two orders of magnitude enhancement of photoelectric conversion efficiency was observed in solar cells made from the DBfA block copolymer as compared to cells made from the $\mathbf{D} / \mathbf{f} \mathbf{A}$ blend. This study demonstrates that, polymer optoelectronic conversion efficiencies could be significantly affected and/or improved via optimizations in spatial regime alone, in this case, the block copolymer nano phase separation due to hydro- and fluoro- carbon differences. Next step research will be to refine the chemical structures such as further increasing the fluorination on $\mathbf{f A}$, adjust or change the bridge unit $\mathbf{B}$, and correlate the chemical structures to solid state thin film morphologies and optoelectronic device performances.

\section{ACKNOWLEDGEMENTS}

This material is based upon work supported in part, by research and educational grant awards from a number of sponsors including the Department of Energy (DOE Award \# DE-EE-0004002), Army Research Office (ARO Awards \#W911NF-11-1-0158 and \#W911NF-15-1-0422), and the National Science Foundation (NSF Award \#1036494).

\section{REFERENCES}

[1] Sun S, Sariciftci N. Organic Photovoltaics: Mechanisms, Materials and Devices, CRC Press: Boca Raton, Florida 2005.

[2] Tang CW. Two layer organic photovoltaic cell. Appl Phys Lett 1986; 48: 183-5. http://dx.doi.org/10.1063/1.96937

[3] Yu G, Gao J, Hummelen JC, Wudl F, Heeger AJ. Polymer photovoltaic cells: enhanced efficiencies via a network of internal donor-acceptor heterojunctions. Science 1995; 270: 1789-91. http://dx.doi.org/10.1126/science.270.5243.1789

[4] Brabec C, Dyakonov V, Parisi J, Sariciftci, N. Organic Photovoltaics: Concepts and Realization, Springer, Berlin 2003.

[5] Gunes S, Neugebauer H, Sariciftci NS. Conjugated polymerbased organic solar cells. Chem Rev 2007; 107: 1324-38. http://dx.doi.org/10.1021/cr050149z
[6] Krebs FC. Polymer Photovoltaics: A Practical Approach, SPIE Press Monograph Vol. PM175, Seattle, Washington 2008.

[7] Sun S, O'Neill H. Sunlight Energy Conversion via Organics, in Handbook of Photovoltaic Science and Engineering, $2^{\text {nd }}$ edition, Luque, A and Hegedus, S., eds., Wiley, the Atrium, England 2011; pp. 675-715.

[8] Chen C, Chang W, Yoshimura K, et al. Adv Mater 2014; 26 : 5670-7.

http://dx.doi.org/10.1002/adma.201402072

[9] Sun S. Design of a block copolymer solar cell. Sol Energy Mater Sol Cells 2003; 79: 257-64. http://dx.doi.org/10.1016/S0927-0248(03)00104-1

[10] Boer B, Stalmach U, Hutten P, Melzer C, Krasnikov V, Hadziioannou G. Supramolecular self-assembly and optoelectronic properties of semiconducting block copolymers. Polymer 2001; 42: 9097-9109.

http://dx.doi.org/10.1016/S0032-3861(01)00388-3

[11] Zhang Q, Cirpan A, Russell T, Emrick T. Donor-acceptor poly(thiophene-block-perylene diimide) copolymers: synthesis and solar cell fabrication. Macromolecules 2009; 42: 1079-82.

http://dx.doi.org/10.1021/ma801504e

[12] Chen XL, Jenekhe SA. Block Conjugated copolymers: toward quantum-well nanostructures for exploring spatial confinement effects on electronic, optoelectronic, and optical phenomena. Macromolecules 1996; 29: 6189-92. http://dx.doi.org/10.1021/ma9605715

[13] Zhang C, Choi S, Haliburton J, et al. Design, synthesis, and characterization of a -donor-bridge-acceptor-bridge- type block copolymer via alkoxy- and sulfone- derivatized poly(phenylenevinylenes). Macromolecules 2006; 39: 431726.

http://dx.doi.org/10.1021/ma060179

[14] Sun S, Brook J, Nguyen T, Zhang C. Design, synthesis, and characterization of a novel c-donor-nc-bridge-c-acceptor type block copolymer for optoelectronic applications. J Poly Sci Poly Chem 2014; 52: 1149-60.

http://dx.doi.org/10.1002/pola.27098

[15] Lee Y, Gomez ED. Challenges and opportunities in the development of conjugated block copolymers for photovoltaics. Macromolecules 2015; 48: 7385-95. http://dx.doi.org/10.1021/acs.macromol.5b00112

[16] Topham PD, Parnell AJ, Hiorns RC. Block copolymer strategies for solar cell technology. J Poly Sci B Poly Phys 2011; 49: 1131-56. http://dx.doi.org/10.1002/polb.22302

[17] Johnson K, Huang Y-S, Huettner S, et al. Control of intrachain charge transfer in model systems for block copolymer photovoltaic materials. J Am Chem Soc 2013; 135: 5074-83. http://dx.doi.org/10.1021/ja3121247

[18] Hiu-Tung C, Zhang W. FluoMar, a fluorous version of the Marshall resin for solution-phase library synthesis. Org Lett 2003; 5: 1015-7.

http://dx.doi.org/10.1021/010274864

[19] Hotchkiss PJ, Li H, Paramonov PB, et al. Modification of the surface properties of indium tin oxide with benzylphosphonic acids: a joint experimental and theoretical study. Adv Mater 2009; 21: 4496-501. http://dx.doi.org/10.1002/adma.200900502

[20] Hotchkiss PJ, Jones SC, Paniagua SA, et al. The modification of indium tin oxide with phosphonic acids: mechanism of binding, tuning of surface properties, and potential for use in organic electronic applications. Acc Chem Res 2012; 45: 337-46.

http://dx.doi.org/10.1021/ar200119g 
[21] Palacios RE, Chang W-S, Grey JK, et al. Detailed singlemolecule spectroelectrochemical studies of the oxidation of conjugated polymers. J Phys Chem B 2009; 113: 14619-28. http://dx.doi.org/10.1021/jp906740n

[22] Zhang C, Harper AW, Dalton LR. Formylation of diethyl 2thienylmethylphosphonate for one-pot synthesis of aminothienostilbenecarboxaldehyde. Syn Commun 2001; 31 : 1361-5. http://dx.doi.org/10.1081/SCC-100104045

[23] Mather BD, Viswanathan K, Miller KM, Long TE. Michael addition reactions in macromolecular design for emerging technologies. Prog Polym Sci 2006; 31: 487-531. http://dx.doi.org/10.1016/j.progpolymsci.2006.03.001
[24] Sun S, Dalton, L. eds, Introduction to Organic Electronic and Optoelectronic Materials and Devices, CRC Press/Taylor \& Francis: Boca Raton, Florida, USA, May 2008.

[25] Zhang C, Sun J, Li R, Black S, Sun S. Synthesis and energy gap studies of a series of sulfone-substituted polyphenylenevinylenes (SF-PPVs). Synthet Met 2010; 160: 16-21.

http://dx.doi.org/10.1016/j.synthmet.2009.09.020

[26] Phelan NF, Orchin M. Cross Conjugation. J Chem Ed 1968; 45: 633-7. http://dx.doi.org/10.1021/ed045p633

[27] Rohr, T; van Eesbeek, M., in Proceeding of the 8th Polymers for Advanced Technologies International Symposium. Budapest, Hungary (13-16 September 2005).

(C) 2016 Nguyen et al.; Licensee Lifescience Global.

This is an open access article licensed under the terms of the Creative Commons Attribution Non-Commercial License (http://creativecommons.org/licenses/by-nc/3.0/) which permits unrestricted, non-commercial use, distribution and reproduction in any medium, provided the work is properly cited. 